http://journal.nafo.int

J. Northw. Atl. Fish. Sci., Vol. 23: 41-73

\title{
History of Fisheries in the Northwest Atlantic: The 500-Year Perspective
}

\author{
W. H. Lear \\ Department of Fisheries and Oceans, 200 Kent Street \\ Ottawa, Ontario, Canada K1A 0E6
}

\begin{abstract}
Along with the discovery of the New World was the discovery of the fish resources of the Northwest Atlantic in the 1490s. The prolific cod populations of the Northwest Atlantic opened up enormous potential as a source of food for Europeans. The fishery, initially operated by fishermen from ports in western Europe, soon provided the basis for settlement of numerous coastal communities in the New World. The groundfish fisheries, solely for cod in the earlier centuries, were important for trade and industrial development and the economic expansion between Europe and the Newfoundland coastal communities. The earlier fishery exploited cod almost exclusively, but later fisheries for other groundfish species, as well as for pelagic species developed. A synoptic overview is presented of the expansion of the groundfish fisheries in the latter part of the 19th Century and 20th Century to the present. The overview attempts to trace the history of fisheries exploitation in its various phases in the Northwest Atlantic from its earliest recorded European beginnings to the present situation. Although various fluctuations have been recorded, the most recent two decades have shown dramatic declines. Because of collapses in some cod stocks and significant declines in other groundfish stocks, moratoria were imposed on major groundfish fisheries in the early-1990s to facilitate stock rebuilding.
\end{abstract}

Keywords: cod, historical overview, Newfoundland Area, Northwest Atlantic

\section{Introduction}

The discovery of the abundance of cod in the waters of the New World, spurred by the increasing populations of Europe and the need for fish, contributed to the early exploration, fishery exploitation and settlement patterns of coastal communities of the New World. The salting process enabled cod to be preserved for relatively long periods of time without significant spoilage and facilitated a market economy based on cod fishing.

The early fishery based almost exclusively on cod developed to include other groundfish and eventually expanded to include all the fishing areas of the northwest Atlantic. The introduction of improved technology such as the cod trap and longlines in the late-1800s and otter trawl technology in the early1900s provided greater and more efficient harvesting power. Coupled with filleting and quick-freezing and an elaborate transportation network, which enabled the products to be distributed to continental North America and beyond, this opened up the possibilities for exploitation of fisheries resources on a greatly expanded scale. Within the past 50 years we have been witness to an unprecedented increased harvesting pressure that can be exerted on fish populations; for example during the $1960 \mathrm{~s}$, when increased productivity and enormous effort enabled record catches of groundfish. This excess fishing pressure led to the eventual precipitous decline in stocks. Management measures were introduced which enabled their eventual recovery. This recovery was followed by severe reductions and eventual collapses of some stocks, notably northern cod. Moratoria were imposed on some stocks to facilitate rebuilding.

This paper reviews events up to and including the 1970s and gives a brief synopsis of the present situation during the moratoria on cod and other groundfish during the 1990s.

To facilitate the discussion of 500 years of history in a single paper, the time period has been arbitrarily divided into sections corresponding to arbitrary historical time periods (Table 1). Each time period 
serves as a focal point to describe the historical developments in the fisheries of the major geographical and political areas of the Northwest Atlantic from New England to Greenland (Fig. 1).

TABLE 1. Outline of sections, time periods and areas discussed in this paper.

\begin{tabular}{|c|c|c|}
\hline Section & Time period & Area \\
\hline $\begin{array}{l}\text { From Discovery } \\
\text { to Utrecht }\end{array}$ & $1497-1713$ & $\begin{array}{l}\text { Newfoundland and the Grand Banks } \\
\text { Gulf of St. Lawrence } \\
\text { New England }\end{array}$ \\
\hline The Expansion Phase & $1713-1783$ & $\begin{array}{l}\text { Newfoundland, Labrador and the Grand Banks } \\
\text { Gulf of St. Lawrence } \\
\text { New England }\end{array}$ \\
\hline Post Revolution to Early Confederation & 1783-1886 & $\begin{array}{l}\text { Newfoundland } \\
\text { Nova Scotia, New Brunswick and Quebec } \\
\text { United States }\end{array}$ \\
\hline $\begin{array}{l}\text { From Commercialism } \\
\text { to Industrialism }\end{array}$ & $1886-1970 s$ & $\begin{array}{l}\text { Newfoundland } \\
\text { Canada } \\
\text { United States } \\
\text { Greenland }\end{array}$ \\
\hline
\end{tabular}

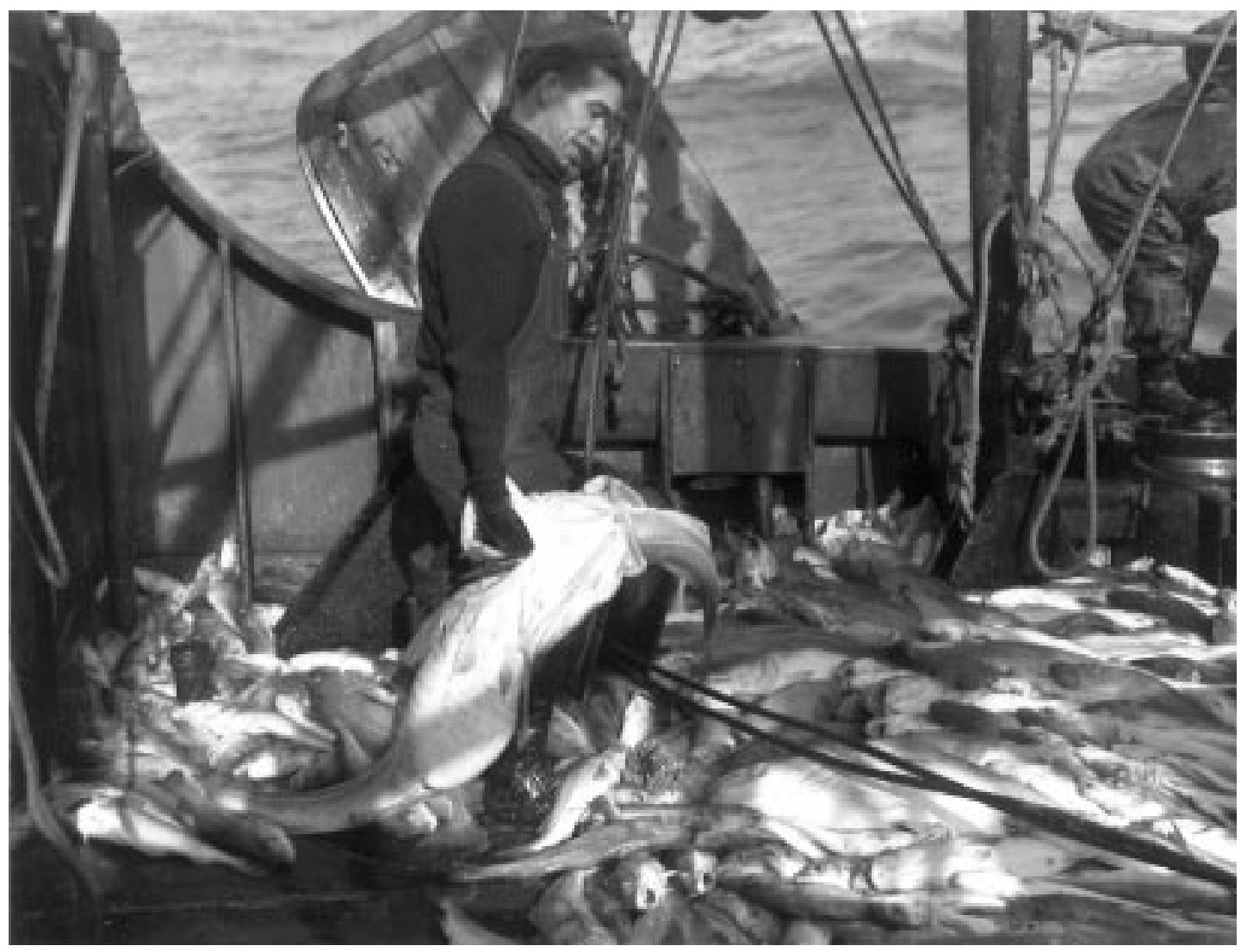

Days of plenty: a catch of cod and haddock on the Grand Bank, 1949. (Courtesy of the National Archives of Canada; Neg. No. PA110814). 


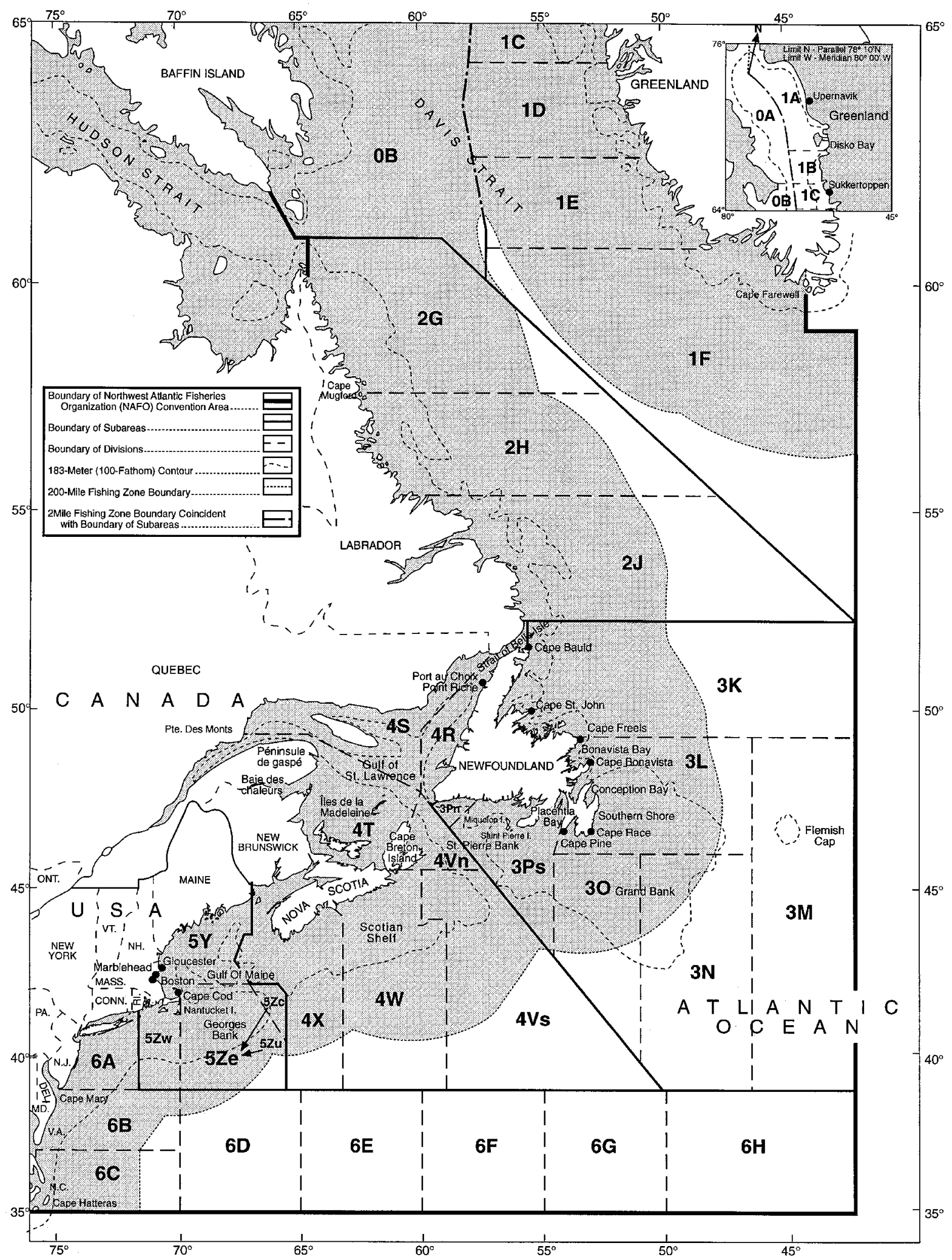

Fig. 1. Area map of the Northwest Atlantic, showing the NAFO Convention Area, 200-mile fishing boundaries and place names mentioned in the text. 


\title{
From Discovery to Utrecht (1497-1713)
}

\author{
Newfoundland and the Grand Banks \\ ".... and they affirm that the sea is covered with fish which are caught not merely with \\ nets but with baskets, a stone being attached to make the baskets sink with the water .... \\ and thus I heard the said Zoane Cabot relate."
}

Thus spoke John Cabot on his return to England from Newfoundland in 1497 (Judah, 1933). Southern Europeans, from Spain and Portugal, called the country which John Cabot had discovered "Baccalaos", the native name for the cod (Pope, 1997). Sebastian Cabot, son of John Cabot, alleged that these fish were so plentiful that they sometimes stopped the progress of his ships (Lounsbury, 1969). The exploitation of the rich resource of the sea in the vicinity of Newfoundland began immediately after the return of the earliest journeys of discovery to the northeastern coasts of North America. The abundance of fish in the New World soon became common knowledge to the people of Europe. To these fishermen, visions of baskets drawn from the seas slopping over with fish, or of their boats bumping and ploughing with difficulty through "great multitudes of big fishes" must have been as glittering as those of gold, silks, or broad lands were to their betters. So during the ensuing century, while kings fought religious and dynastic wars, fishermen, unconcerned, desiring only to be unmolested, went in ever increasing numbers to the North American waters (Judah, 1933).

The Portuguese had begun fishing in Newfoundland waters by 1501, and French fishermen - Normans and Bretons - had appeared by 1504. French and Basques were also fishing for Newfoundland cod in the early-1500s. England, although it claimed title to the Island, found it more convenient to utilize other fishing grounds closer to Britain in the first half of the century. There were few English fishermen at Newfoundland before 1565 (Pope, 1992). However, with the failure of their fishery around Iceland at mid-century, an increasing number of British fishing interests turned their efforts toward exploiting the Newfoundland cod stocks (Lounsbury, 1969). Historic records thus show that the Portuguese, French and Spanish, followed by the English were the first to engage in the Newfoundland fishery.

In the early 16th Century the Portuguese prosecuted the fishery in southern Newfoundland. The French fishery became relatively important soon after and ships from the French Channel and Bay of Biscay ports carried out fishing in the neighborhood of the Strait of Belle Isle and to the south of Newfoundland. Apparently by about 1575 the French began to develop a bank fishery (Turgeon, 1987). The Portuguese prosecuted the fishery in southern Newfoundland. The Spanish fishery increased rapidly after about 1545 and declined rapidly toward the end of the century. The Basques were noted for prosecuting a dry fishery. They did not engage in a wet or offshore fishery (Denys, 1968). In the more southerly regions of Europe, they had access to cheaper supplies of salt which was obtained by evaporation of sea water, and these countries sent out ships from a relatively large number of scattered ports and brought back the larger, salted fish for an important home market (Grant, 1934). The English cod fishery at Newfoundland, on the other hand, began to expand significantly after the mid-century, especially in the 1580 s after the destruction of the Spanish and Portuguese fisheries at Newfoundland. This provided England with the golden opportunity to supply the Southern European markets (Rowe, 1980).

Also about this time the population of England started to increase more rapidly than it had previously, and the growth of the English Navy and England's military expeditions to Ireland and elsewhere created a large and continuous demand for food in the form of fish (Rowe, 1980). The lightly salted, hard, sun dried product which the British favored, required sun and wind and also demanded a land based operation (Fig. 2). This led to settlements devoted to the curing of cod destined for the English trade and was mainly responsible for the pattern of settlements in southeastern Newfoundland from Cape Freels in the north to Cape Pine (Fig. 1) in the south (Matthews, 1988). The English settled in this area because of the proximity to the cod resource, and also because they were generally precluded from the northern areas, specifically from Cape St. John to Cape Bauld (Fig. 1) by the French. Thus the availability of the cod resource and the constraints of the curing method predicated the pattern of English settlement in Newfoundland. 


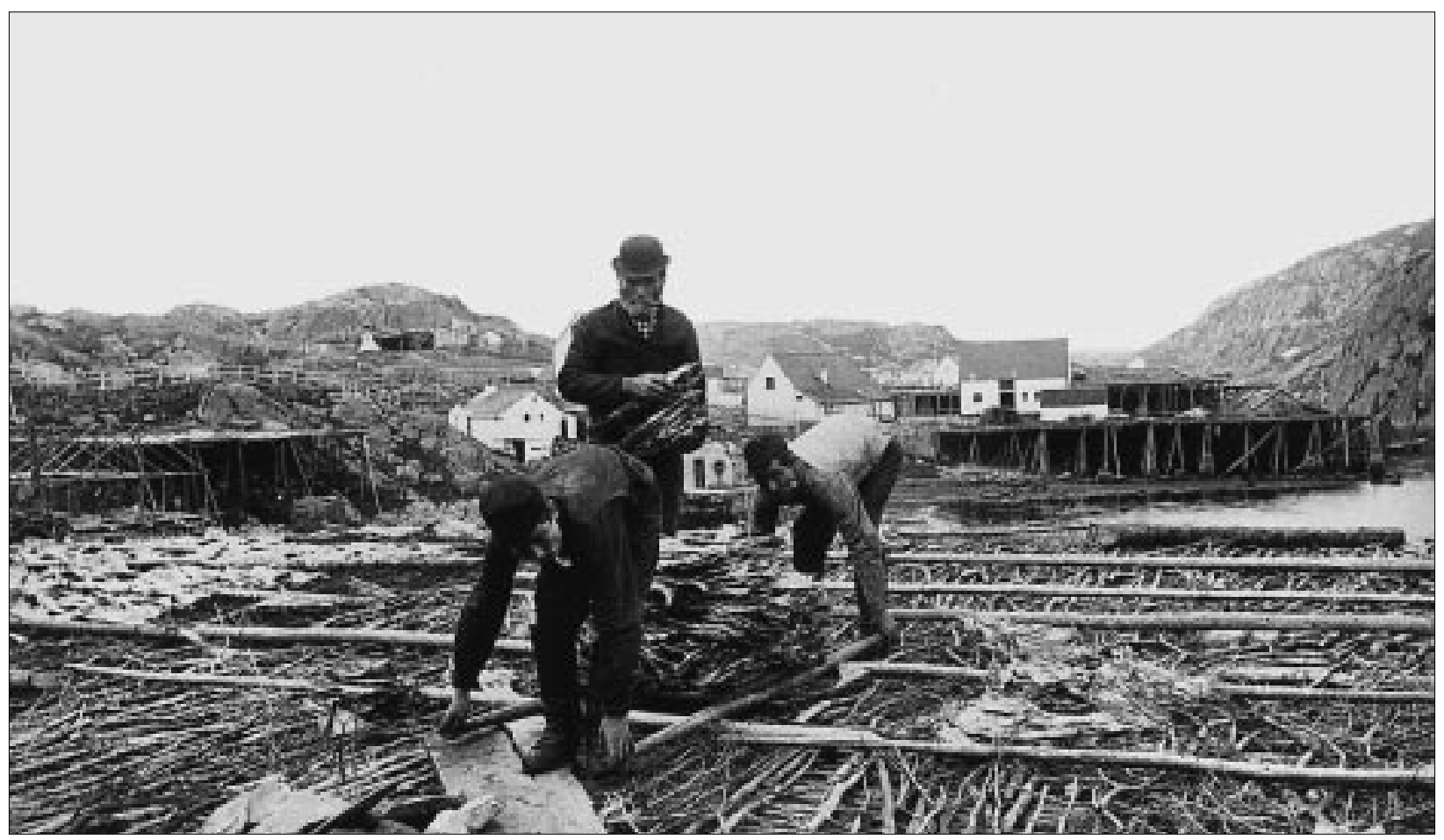

Fig. 2. Loading dried cod on the hand barrow, from the drying flakes, Newfoundland, 1886. (Courtesy of National Archives of Canada; Neg. No: PA139025).

Fishing at first was carried out by migratory fishermen from Spain, Portugal, France and England, who sailed to Newfoundland in spring and returned in autumn with cargoes of salted fish. For the salting, the English fishermen built stages, flakes, (Fig. 3) warehouses and living quarters to which they returned annually (Ryan, 1986). As these holdings increased in size and became valuable, especially from the vantage point of location, caretakers were left behind over the winter to build new premises, rebuild old ones and to have everything ready for an early start when the fishing ships arrived from England. These caretakers, plus deserters from the fishing ships, became the first European residents (Ryan, 1986).

Newfoundland was catering to a cod fishery and, if nothing else, the fluctuations in population reflected this. Thus, while on the mainland the population increased steadily and continuously, in Newfoundland it fluctuated considerably partly in response to the effects of war on the fortunes of the fishery. Occasionally, wartime catastrophes stranded normally migratory crews in Newfoundland. However, by 1700 there was an overwintering population of about 2000 (Pope, 1992). In 1715 there were 4049 inhabitants; in 1720 only 2320 (Matthews, 1988). The size of the population depended on conditions in the fishery, but the existence of the migratory fishery because of the proximity to Europe, rendered it unnecessary for men who wanted to fish to have to live in Newfoundland permanently. During the period 1660-85, wars and failures of the fishery ruined many of the planters, who had established fishing premises in Newfoundland. For a few years things improved and a number of new planters arrived to commence business, but in 1689, King William's War between England and France created fresh problems. This war, with an intermission between 1697 and 1701, lasted until 1713, when it terminated with the Treaty of Utrecht (Matthews, 1988). Until 1693 the population probably increased owing to the embargo, between 1689 and 1692, on English fishing ships coming out to Newfoundland. For the merchants this left only the settlers to carry on the fishery (Matthews, 1988). In the years 1695-97 there occurred the devastating French attacks, which destroyed almost every settlement and removed most of the settlers. Peace in 1698 saw a sharp rise in population, which came to an abrupt end with the outbreak of war in 1701. The war against France brought complete ruin to the settlers. The restoration of peace in 1713 with the Treaty of 


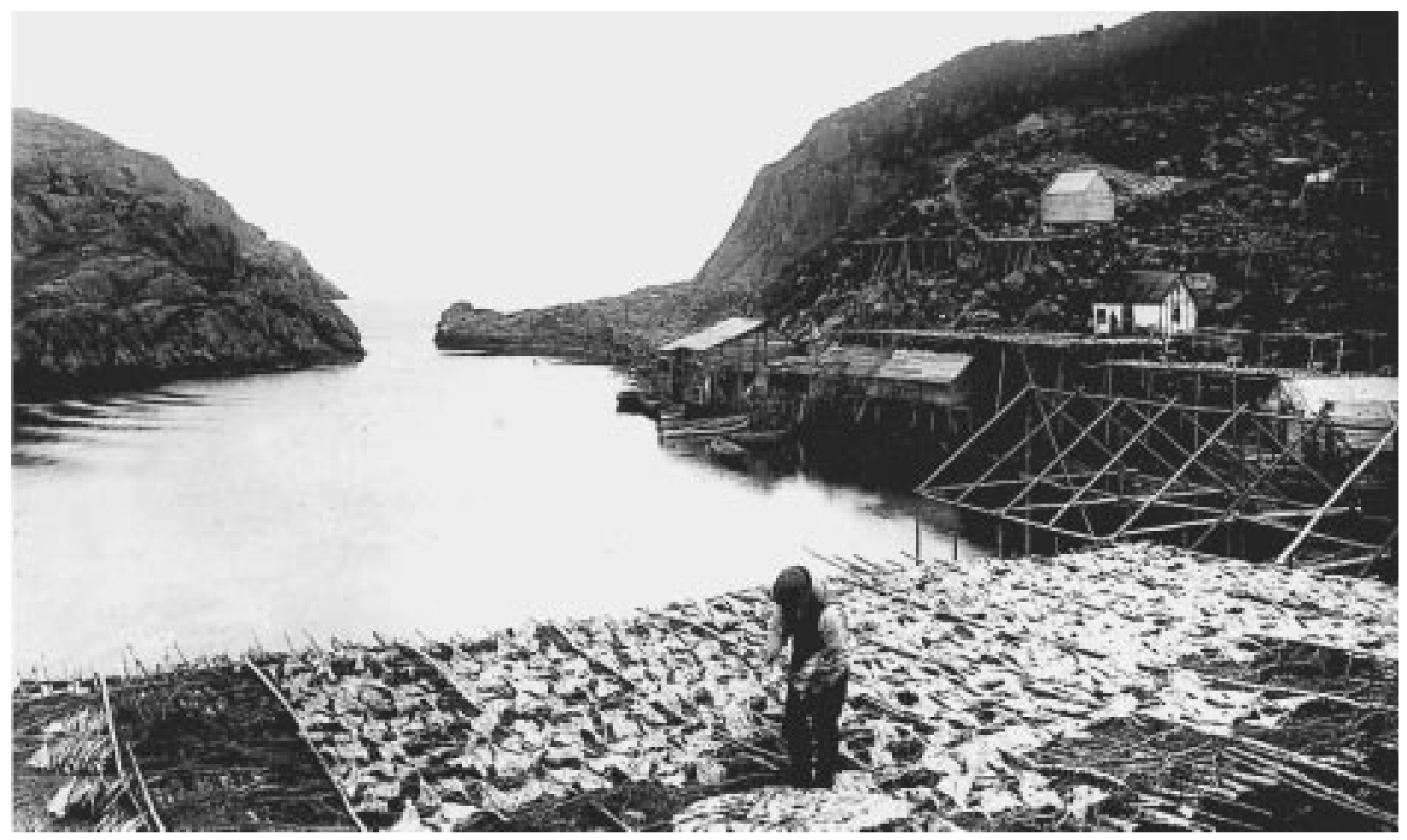

Fig. 3. Cod drying on flakes in Newfoundland showing stages, flakes and waterfront necessary to conduct the traditional inshore fishery. (Courtesy of National Archives of Canada; Neg. No: C27881).

Utrecht did little to help, because by then there had begun a prolonged failure in the fishery which continued until the late-1720s (Matthews, 1988).

An Act of the English Parliament, called King William's Act, passed in 1699, represented an attempt to recognize the need for settlement while at the same time preventing it from growing. The Act attempted to define migratory and planter shore properties so that they would not compete for the same spaces on shore. Laws relating to the ownership of land were revised and codified so that the rights of private landowners were clearly distinguished from the public land which was reserved for the use of visiting fishing ships (Matthews, 1988).

There were limited numbers of premium spaces for shore-based fishing, and the migratory ship fishermen and year-round inhabitants would be competing for the same fish and for the same spaces along the shore. As early as 1683 the problems of over-fishing and over-capacity were recognized. Head (1976) provides the following quote from the Colonial Office Records in the Public Records Office, London:

\begin{abstract}
"though there be Harbours and conveniences on shore for the making of Fish there is not fishing ground or can constantly be fish enough for so many Boates as they have kept, as is evident, for they seldom make good Voyages above once in three Years, whereas were there but half so many Boates fish there, they could not make so great a Destruction One Year as to prejudice the next years fishery."
\end{abstract}

It was not merely the pressure for shore space that was important but also the quality and location of that space. Even in cramped harbours, such as St. John's, there was indeed ample room, but certain pieces of shore were favored. Some were nearer the fishing grounds, and from them less rowing time was spent; the fishing activities were fatiguing enough without excessive added rowing, frequently against heavy 
winds and waves (Fig. 4). Shelter within a secondary cove was also an advantage, for this reduced wear and tear on boats and reduced the risk of damage to stages from heavy seas. A good beach of well-sorted gravel, even if small in area, allowed at least some fish to be cured on the beach without the use of flakes (Fig. 5). Particular sections of a harbour with superior combinations of these attributes became esteemed and were competed for vigorously by the first-arriving ships, the earliest of whose masters would become "admiral" of that harbour for the summer (Head, 1976).

\section{Gulf of St. Lawrence}

In 1534 Jacques Cartier visited Newfoundland and sailed up the Gulf of St. Lawrence to Bay Chaleur (Prowse, 1895). Cartier made a second voyage in 1535 and a third voyage in 1541. At this time there were 60 French fishing ships in Newfoundland.

The Basques or Biscayans, as they were locally called, began to engage in the cod fishery off Newfoundland about 1545 . Besides the cod fishing, the Basques carried on a very extensive whale and seal fishery both in the Gulf of St. Lawrence and further northward. Their land bases were in the Gulf and Strait of Belle Isle, collectively called the Grand Bay. The Basques used to continue their summer operations in the Gulf until December (Prowse, 1895). There was little evidence that the English had penetrated into the Gulf of St. Lawrence through Cabot Strait until after 1588. The first English vessels went to the Magdalen Islands in 1593 to participate in the walrus fishery. During the late 16th Century the English also fished sporadically off Cape Breton (Innis, 1940). The Portuguese fishery in the late 16th Century,

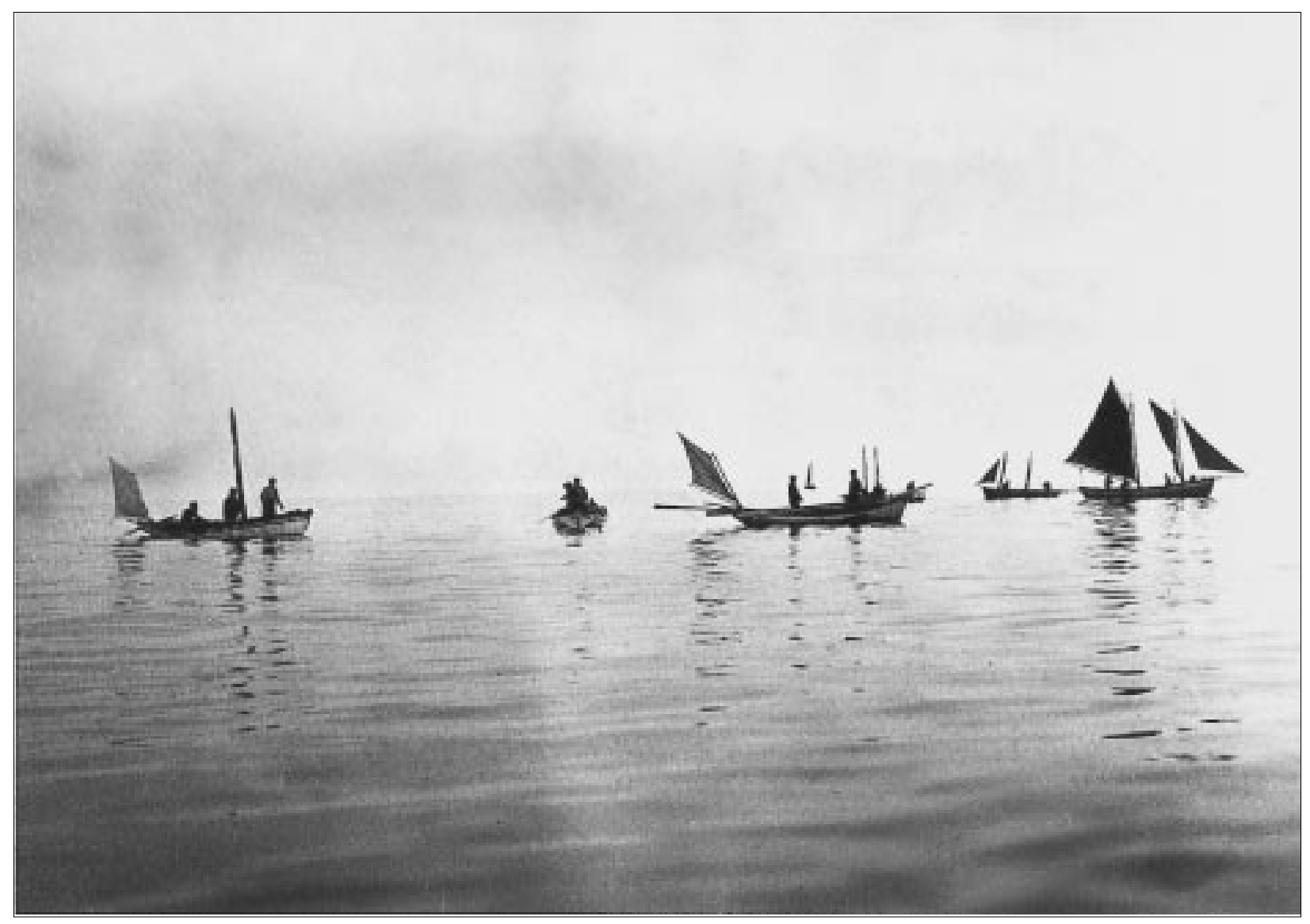

Fig. 4. Inshore fishing boats, powered by sails and oars, handlining for cod, 1907. (Courtesy of the National Archives of Canada; Neg. No: C37556). 


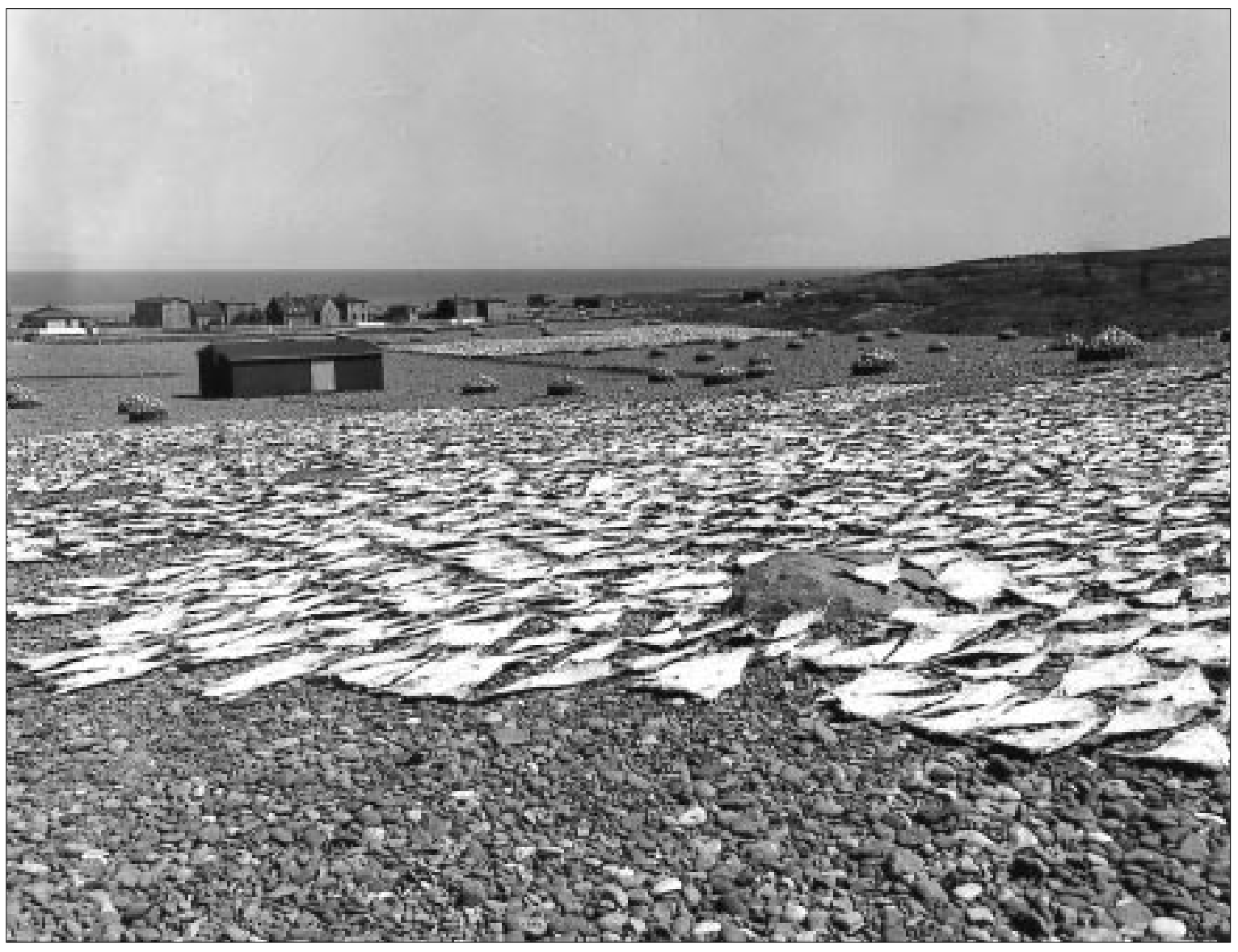

Fig. 5. Codfish drying on a beach in Newfoundland, 1949. (Courtesy of the National Archives of Canada; Neg. No: PA110812).

comprising about 58 ships, was engaged in fishing in the Gulf of St. Lawrence and Cape Breton as well as at Newfoundland. The Portuguese engaged in the fishery from April to July (Innis, 1940).

\section{New England}

The discovery of one now-famous part of New England resulted from the search for a commodity completely apart from codfish but in which the cod had a featured role. On March 26, 1602, the ship Concord, commanded by Bartholomew Gosnold, departed Falmouth, England headed for the shores of the New World. Gosnold had two objectives: to trade with the natives and to search for sassafras trees.

Gosnold's records note that on May 14, 1602, the Concord reached "a mighty headland." Aboard the ship was adventurer, Gabriel Archer who told of the naming of the headland: "... we had again sight of the land, which made ahead, being as we thought an island, we called it Shoal Hope. Near this cape we came to anchor in 15 fathoms, where we took great store of codfish, for which we altered the name, and called it Cape Cod" (Jensen, 1972).

Fishermen were not far behind this voyage of discovery. As a result of Gosnold's reports on the abundance of codfish, Bristol merchants provided Martin Pring with two vessels to explore the cod resources. In 1603, Pring arrived off the coast of the Strand and found that Gosnold had not exaggerated. The land, too, he found well suited to the shoreside activities of the fishery, providing not only an abundance of cod but also an abundance of rocky ground on which to dry the product for shipment back to Europe. 
Early New England colonists relied on fish for subsistence during their first, difficult years of settlement. By the early 17th Century the New England colonists were fishing for cod in local waters (Jensen, 1967). In 1624, "not less than 50 vessels from Gloucester" fished with handlines in the offing of Maine and Massachusetts (Babson, 1860, quoted in Jensen, 1967). In 1653, a minister from Salem, Massachusetts urged local communities and English businessmen to invest in the infant fishing industry. That same year, the General Court of Massachusetts Bay established a fishery management commission, and several years later, exempted fishing vessels and equipment from taxation. New laws were enacted to improve the quality of marketed fish and close the cod and mackerel fisheries during the spawning season. These policies remained in place throughout the colonial period (Kunzig, 1995).

Fishing quickly became New England's major maritime industry as the fishing fever spread north and south to coastal villages such as Marblehead, Ipswich, Monhegan, Scituate and Barnstable. Many early groundfish fishermen chose to operate within a day's sail from their home ports to the fishing grounds of Jeffries Ledge and Stellwagen Bank (Fig. 6). Cod, haddock and pollock became the backbone of New England's export trade. Others ventured farther offshore to the fertile waters of Georges Bank and the Gulf of Maine. Soon thousands of "Yankee" fishermen aboard hundreds of boats were also travelling to the Grand Banks off Newfoundland each year (Fordham, 1996).



Fig. 6. Small inshore fishing boat, rigged with sails, in front of Percé Rock, Quebec, 1932. (Courtesy of the National Archives of Canada; Neg. No: PA56660). 


\section{The Expansion Phase (1713-1783)}

\section{Newfoundland, Labrador and the Grand Banks}

In 1713, the Treaty of Utrecht, which ended the long war between England and France, placed Newfoundland in a unique situation. The French government gave up its colony on the south coast and acknowledged that the entire Island belonged to England, thus agreeing that the Island was fully a sovereign possession of England. As with other territories settled by or ceded to England, French permanent settlements in Newfoundland now became illegal. Yet the other normal attributes of sovereignty did not follow, for French fishermen were by Treaty given the right to use the harbours along the coast between Cape Bonavista and Point Riche (Fig. 1) during the fishing season. They were, however, forbidden to stay during winter or to erect any kind of buildings "besides stages made of Boards and Hutts necessary and usual for drying of Fish". Thus began the French Shore in Newfoundland, an unusual diplomatic device which, as almost inevitably happens with ambiguous international agreements, led to more or less constant friction between English and French fishermen and caused sporadic irritation between the English and French governments to the present century (Matthews, 1988).

The period after 1713 was a period of evolution and changes and, in the end, increasing prosperity in the fishery. English settlements, confined until 1713 to the area between Bonavista Bay and Trepassey, began to spread. They spread first into St. Mary's Bay and Placentia Bay, then to Fogo and Twillingate, up into the French Shore on the Northern Peninsula, into Fortune Bay and eventually, after 1763, up into Labrador. The organization of the fishery changed too, with the old style fishing ships from the West of England disappearing, except in one or two areas, to be replaced by a new fishing vessel, the banker which took its fish in the Grand Banks and brought it to land for curing (Matthews, 1988). The innovation of banker vessels in the English fishery was precipitated by the failure of the inshore fishery. In 1715 a Devonshire ship owner fishing at Renews, along the Southern Shore due south of St. John's (Fig. 1), found the inshore fishery so bad that in desperation he sent a shallop (an open fishing boat) fishing on the Grand Banks. It made a "saving voyage", a local expression for a good catch of fish, and in turn eventually saved the migratory fishery - especially that part which came from south Devonshire. The Grand Bank fishery grew steadily between 1715 and 1760, but it expanded significantly after the Seven Years' War which ended in 1763. In the years between 1765 and 1775, more than 200 bankers a year sailed from west country ports in England to fish the Grand Banks (Smallwood, 1967). During this period the "bye-boat" keepers flourished and reached their greatest importance in the fishery. Bye-boat keepers were servants carried as passengers on fishing ships to Newfoundland, where they were employed in private boats to catch and cure fish, and after the fishing season they were brought back to England (Head, 1976). By the 1770s there were more than six thousand men brought annually as passengers on the Bank ships (Matthews, 1988).

The expansion of the English cod fishery to northeastern Newfoundland after 1713 was also in part necessitated by a collapse in yield in southeastern Newfoundland that occurred in the mid 18th Century (Head, 1976). The catch rates declined from about 400 quintals or more (a quintal was 112 pounds of split, salted, dry cod.) in every major region to about 150 quintals along the Southern Shore (Fig. 1) and in Conception Bay in the mid-1750s, (Forsey and Lear, 1987). It is presumed that extended heavy exploitation of the inshore cod may have contributed to falling catches since the stocks did not appear to recover until the fishing pressures were reduced. The fishery on the offshore banks offered some relief from the low inshore yields. The northern cod fishery was supplemented by other natural resources. Atlantic salmon, seals and to some extent furs added a good deal to the income from cod, especially during the great decline in inshore cod yield after the 1740s (Head, 1976).

During the period 1760-75 the inshore cod fishing was the mainstay of Newfoundland involving about 2200 boats which produced nearly half a million quintals of salted, dried cod. The bank fishery by the late-1760s and early-1770s was producing around 100000 quintals of fish. By 1781 the inhabitants landings had declined to 120000 quintals from 230000 quintals in 1775, probably in response to slackened 
pressures on the fishing grounds during the American War of Independence. The yields per boat began to improve again during the 1780s (Head, 1976).

\section{Gulf of St. Lawrence}

After the Treaty of Utrecht (1713), the French withdrew from Placentia Bay in Newfoundland, Hudson Bay and Nova Scotia (Innis, 1940). They consolidated their holdings at Louisbourg in Cape Breton and Prince Edward Island (which they called Isle St. Jean). These fisheries were handicapped by a fishery conducted from a wide range of ports in France, each with widely separated fishing regions in the New World. It was estimated that the French had 1200 vessels on the Grand Banks, and that these vessels made voyages without entering a port in North America. Around the Gaspé Peninsula, large vessels continued to fish at Caraquet and Port Daniel, and small boats at location such as Pabos in Chaleur Bay, Grand Etang, Matane and other locations. The number of vessels along the North Shore of the Gulf of St. Lawrence varied from 13 to 18 during 1726 to 1743 . There were about 1000 to 1500 men employed, who caught about 33000 to 55000 quintals of fish (Innis, 1940). Fishing vessels went from Quebec, as well as from France, to participate along the North Shore for fishing and sealing.

In addition to the French, the Basques also fished in the northern Gulf of St. Lawrence, specifically at Port au Choix on the west coast of Newfoundland. After 1713, the Basques also extended their fishery to include the south coast of Newfoundland.

The French salted their cod in the holds of their ships. These green cod were taken chiefly in the Gulf of St. Lawrence, on the Grand Banks, St. Pierre Bank and off Sable Island by double decked vessels of from 100 to 150 tons. Each vessel brought home to France about 30000 to $35000 \mathrm{cod}$. They were sold in different places and salted according to size; e.g. great cod - 90 to 100 pounds, middling - 60 to 100 pounds, and small - less than 60 pounds.

These size classes give an indication of the abundance of large cod that were obtainable during this period (Fig. 7).

By 1763, the fishery was divided between this important branch conducted by fishing ships at Gaspé, the North Shore, Labrador, and on the offshore Banks and the other branch composed of a complex resident, inshore sector fishing at Cape Breton, which employed no fishing ships (Innis, 1940). After the Treaty of Paris in 1763 the French were given the right to the shore fishery between Cape Bonavista and Cape Race but they were not allowed to fish within three leagues of shore in the Gulf of St. Lawrence or within 15 leagues of the coast of Cape Breton. The French fishery declined after 1770 and, with the retreat of the French from Cape Breton and the Gulf of St. Lawrence, these areas were rapidly occupied by the English. After the Treaty of Paris (1763), the French-speaking Jerseymen (men from Jersey, one of the Channel Islands belonging to England), who were used to visiting French sites in the Gulf of St. Lawrence as crew on the St. Malouin fishing vessels, were particularly suited to take over these fishing places. Some Jersey firms were soon set up in Gaspé as well as in Newfoundland. There was an expansion of Jersey fishing enterprises into the Gulf of St. Lawrence and the south coast of Newfoundland which tended to distance the Jersey merchants from those of the West England (Ommer, 1991). Jerseymen were sending 70 to 80 vessels to the new Gaspé establishment by 1785 .

At Cape Breton, which the French called Isle Royale, a French fishery had existed from the 16th Century. After 1713, the French swiftly moved to transfer their settlement from Placentia, Newfoundland to Isle Royale. The period from 1718 to late-1730 was marked by high production (110 000 to 170000 quintals). There was a marked decline in production during the 1740 s (70 000 to 90000 quintals) and a final period of low production of about 80000 quintals in the 1750s (Balcom, 1984). The catch-per-unit effort dropped from 180 quintals per boat in 1739 to 30 quintals per boat in 1743. Production was almost entirely concentrated on dried cod. Other food fish such as herring or mackerel were used only as bait (Balcom, 1984). 




Fig. 7. Large cod fish from the trap, Battle Harbour, Labrador around 1910. The larger fish measured 5 feet, 5 inches and weighed 60 pounds. (Courtesy of the National Archives of Canada; Neg. No: C76178).

\section{New England}

As early as 1708 New England vessels were venturing as far away as the Nova Scotian Banks (Jensen, 1972). By 1731 there were between 5000 and 6000 fishermen in Massachusetts alone. Of the 400 vessels sailing out of Massachussetts, 160 were out of Marblehead (Jensen, 1972). By 1741, Massachusetts had about 400 fishing vessels and an equal number of smaller shallops and undecked vessels. In 1745 the production of New England was estimated at about 230000 quintals. Although the fishery resources (whales) of Georges Bank were first tapped regularly in the early 18th Century by New England whalers about 1715 (German, 1987), the first recorded catch of cod from Georges Bank did not occur until 1748. By 1757 Gloucester vessels were sailing further away and were fishing mainly on the Grand Banks (Merriman, 1982), where they joined vessels from England, France, Spain and Portugal (Fig. 8). By 1788 as many as 60 vessels were fishing on the Grand Banks. By the end of the 17th Century, the cod had earned a place in the Massachusetts State House as a symbol of the region's prosperity (Fordham, 1996).

By the time of the American Revolution, the New England cod fisheries involved more than 500 boats and 5000 cod fishermen. Another 10000 people were employed by shore-based processing and marketing industries. Boats from more than 20 different ports were cod fishing, with Gloucester and Marblehead bringing in $60 \%$ of the catch (Albion et al., 1972).

The expansion of the New England fishery was chiefly in response to the demands of the British and foreign West Indies. Good quality fish went to Europe, and refuse fish to the West Indies. In 1750, out of 


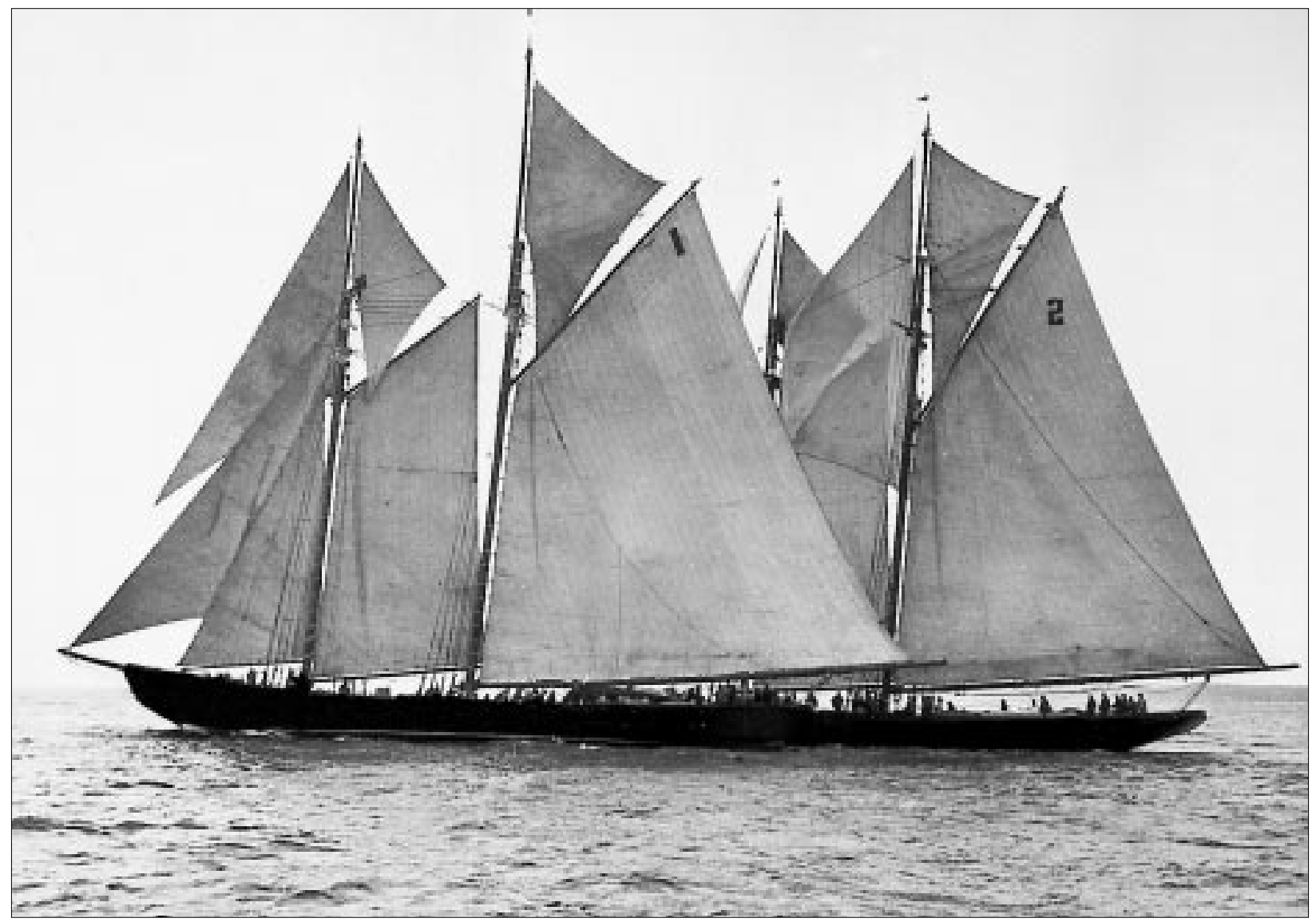

Fig. 8. International fishing (banking) schooners, with the Bluenose in the lead off Nova Scotia. (Courtesy of the National Archives of Canada; Neg. No: C284).

the whole catch from 400 vessels in the fishery, half went to the West Indies in addition to the catches from 200 vessels engaged in fishing for mackerel, haddock, hake, pollock and scale fish. In 1763, Massachusetts, with 300 vessels took 102265 quintals of good quality (merchantable) fish and 137794 quintals of refuse fish (Innis, 1940). The same ships that took cod to Europe were used to transport Africans back to the New World as slaves. The cod was thus one of the essential props in a three-cornered trade that is often called "The Golden Triangle" (Jensen, 1972).

\section{Post Revolution to Early Confederation (1783-1886)}

\section{Newfoundland}

The American War of Independence (1776-83) resulted in a decreased migratory fishing activity in Newfoundland. The Bank fishery which numbered some 150 to 200 vessels before the American Revolution had fallen off to negligible numbers during the war. When the war ended, the fleet quickly increased again so that by 1788 there were about 280 vessels engaged in the bank fishery (Head, 1976). Because of high prices and increased effort, the year 1788 brought the greatest number of Bankers ever. The catches were exceptionally good and led to a total offshore catch never experienced in earlier years. In the area around St. John's and the Southern Shore, the Banks catch alone rose to 289000 quintals, about two to three times the offshore Banks catch that could be expected from this area in earlier years. The glut of fish from the Banks plus the catches from the inshore areas flooded the inelastic market for Newfoundland dried cod and resulted in very low prices and large quantities of unsold fish. The total production of 
950000 quintals, a significant increase from the usual 500000 to 600000 quintals per year in the preceding years, plus the poor condition of the fish ("thin lomey kind") gave a net return lower than if a normal catch had been made. As a result of an increased resident population (25000 in 1790) and a reduction in the number of migratory fishermen, the migratory fishery began a general decline. By 1805 residents outnumbered visitors by four to one and by 1815 five to one. The bye-boat keepers had disappeared from the fishery by 1815 . The Bank ships could no longer make a steady profit and thus the mainstay of the migratory fishery was failing. An increased population rendered it less necessary, and the changing social and economic circumstances made it uneconomical (Matthews, 1988). The number of men in the inshore fishery increased and landings rose accordingly for a while. The yields then fell significantly. Yields per boat on the Southern Shore fell from 300 quintals per boat to less than 200 by 1786 and down to as low as 150 quintals in 1788 and 1791. Catch failures occurred. At Placentia the catch in 1793 was the worst ever in memory. By July 25 at St. Lawrence, the inshore boats had taken only 60 quintals (Head, 1976).

During the Napoleonic War, many fishermen from the Newfoundland southeast coast, particularly Conception Bay, became engaged in a migratory cod fishery on the North Shore in the area between Quirpon and Cape St. John, a part of what was the French Shore. The Newfoundland fishermen occupied the fishing areas vacated by the French at the outbreak of the war. The men and ships participating in this fishery were mainly the same ones engaged in the spring seal fishery (Ryan, 1986). Out of this North Shore fishery there grew the Labrador fishery (Fig. 9) as vessels would occasionally continue on to the Labrador coast to secure a catch if the fishery along the North Shore was poor (Fig. 10).

By the late-1820s the Labrador fishery was firmly established. It consisted of two types of fisheries in addition to the small resident fishery. Migratory fishermen from the island of Newfoundland were known as:

1. "Stationers" who established themselves on shore at a "room" and who caught and cured their fish in one place;

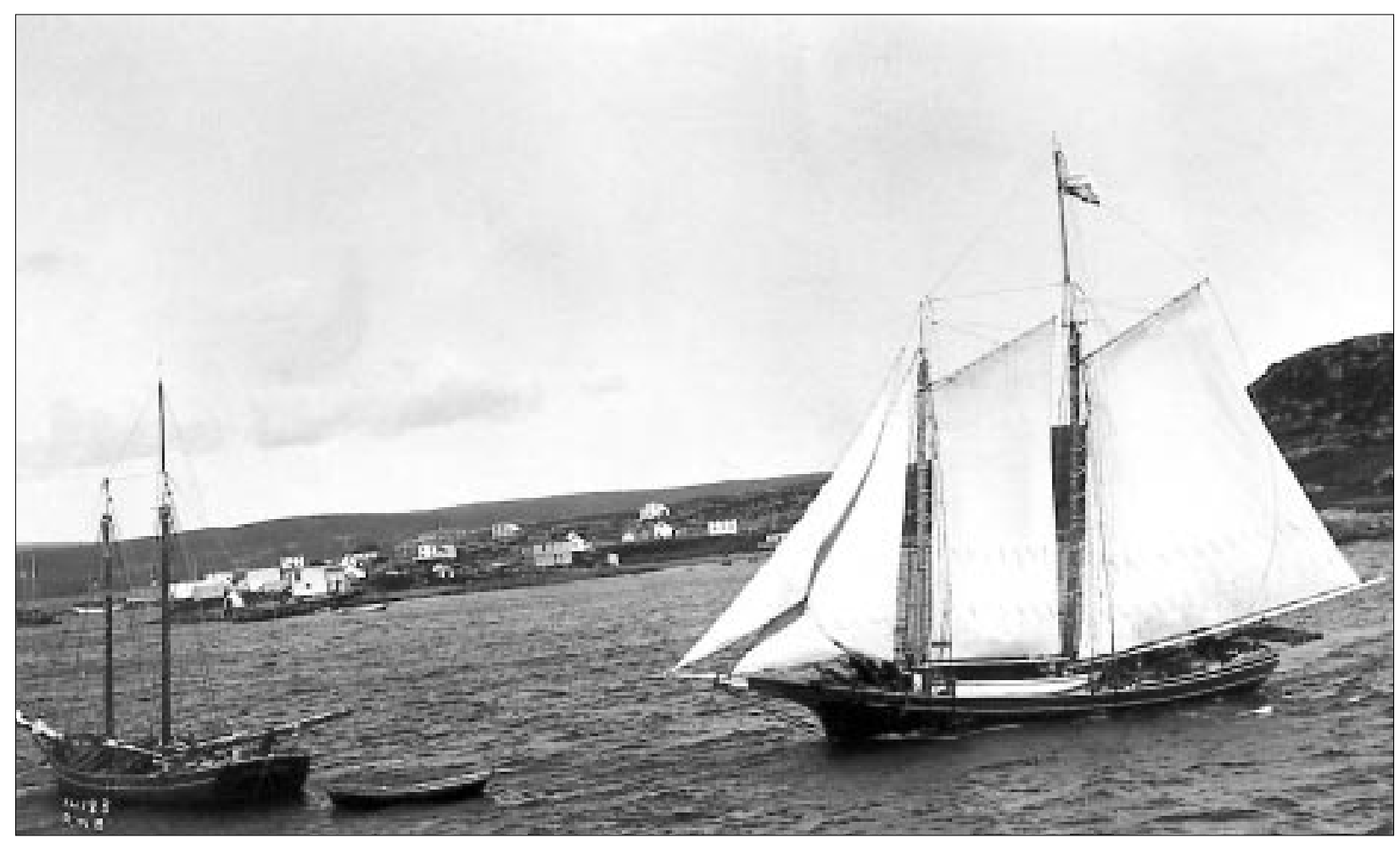

Fig. 9. Fishing schooners arriving at St. Anthony, Newfoundland from the Labrador fishery, 1910. (Courtesy of National Archives of Canada. Neg. No: PA45310). 
2. "Floaters" who lived on board their schooners and moved around to the various fishing grounds and generally salted their catch on board and brought it back to the island to be dried.

At its peak the stationer fishery generally operated along the southern coast of Labrador and did not extend north of Cape Harrison. The floaters extended their fishery farther north than the stationers until they were fishing as far north as Cape Chidley (Fig. 1). The Labrador fishery, during its peak and in conjunction with the seal fishery, provided the Conception Bay - St. John's area and to a lesser extent, Trinity Bay and points north with a basis for greater population concentration than could be expected from the shore fishery alone (Ryan, 1986).

The traditional methods of the inshore fishery, mainly handlines operated from small boats (Fig. 4), that prevailed in the 18th Century generally continued on into the 19th Century. Cod seines were used to a very limited degree as were gillnets (called cod nets) (Grenfell, 1909). An exception was the introduction of the cod trap, invented in 1866 by Captain W. H. Whiteley in the Strait of Belle Isle. Essentially this was a modification of the seine used to catch cod and salmon. Unlike the seine, which was pulled around a school of fish, the cod trap was stationary (Fig. 11) and the fish had to be led into a box-like trap by a leader of netting. The use of the cod trap had become widespread by the last decade of the 19th Century because of its applicability to the shore fishery and to the Labrador fishery and may have partly accounted for the increased production of cod during the late 19th and early 20th Century (Ryan, 1986). The number of traps increased from 2588 in 1891 to 4182 in 1901 (Innis, 1940). It is interesting to note that this was approximately the number of traps in use in 1990 (about 4 000). Also during this time the use of longlines from which hundreds of baited hooks were suspended (commonly called bultows) began to be adopted mainly by the banks fishery. Their use was prohibited on many inshore fishing grounds (Anon., 1943).

Also during the 1860 s steam power was introduced into the seal fishery and as a result into the supplementary Labrador fishery. This did not change the catching efficiency of the inshore fishery but it enabled larger cargoes of fish to be carried to market than ever before and caused market gluts (Ryan, 1986).

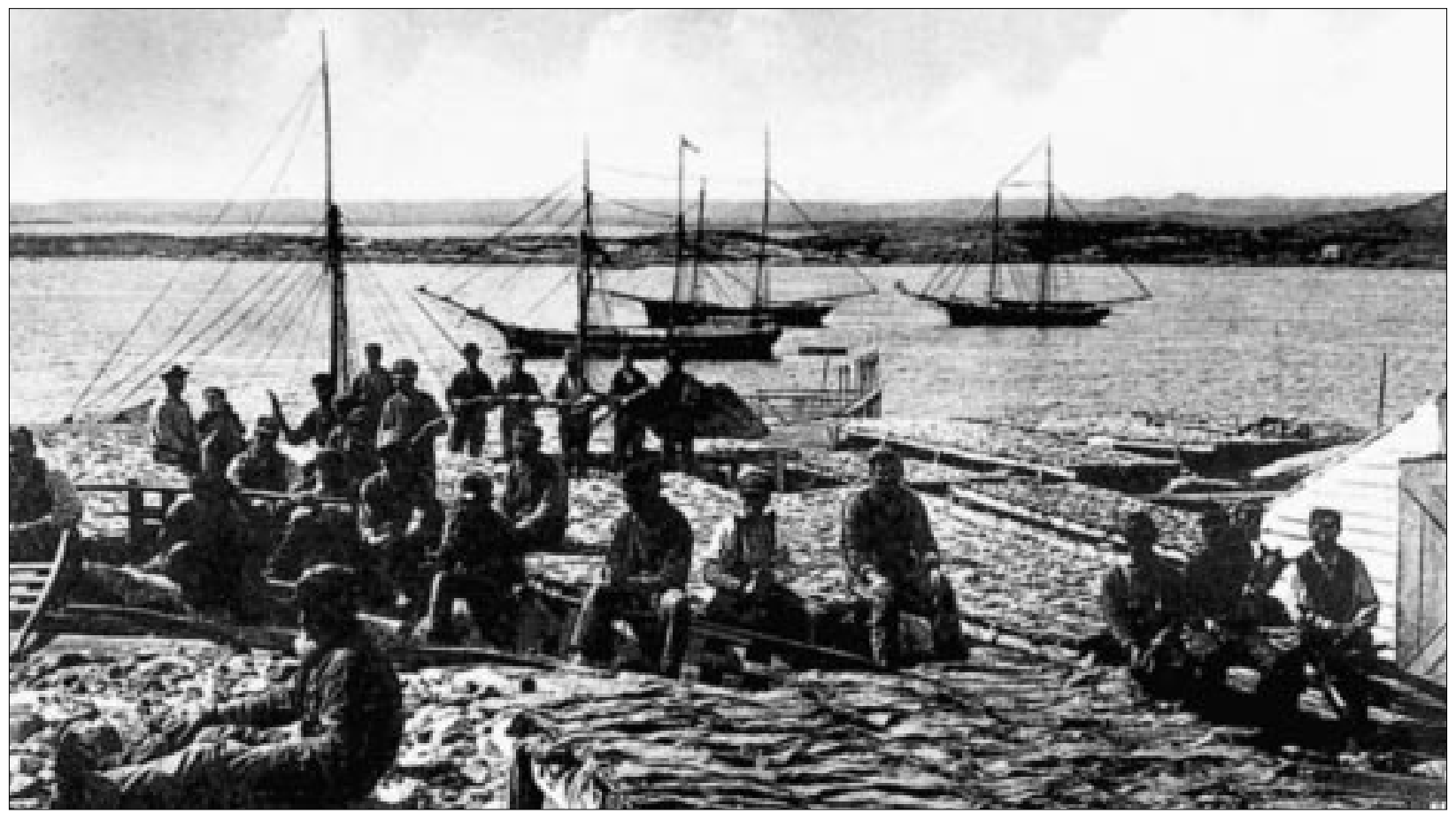

Fig. 10 Newfoundland fishermen, with cod drying on the flakes, and Labrador schooners in the background. (Courtesy of the National Archives of Canada; Neg. No: C74893). 
Catches of cod from eastern Newfoundland and Labrador averaged about 200000 tons (about 807000 quintals) during the mid-1860s and about 260000 tons (about 1049000 quintals) during the early-1870s (Fig. 12). This period of the 1860s was reported as being disastrous for the entire Island of Newfoundland (Smallwood, 1967). The cod and herring fisheries failed and the seal hunt suffered a decline. Fishermen

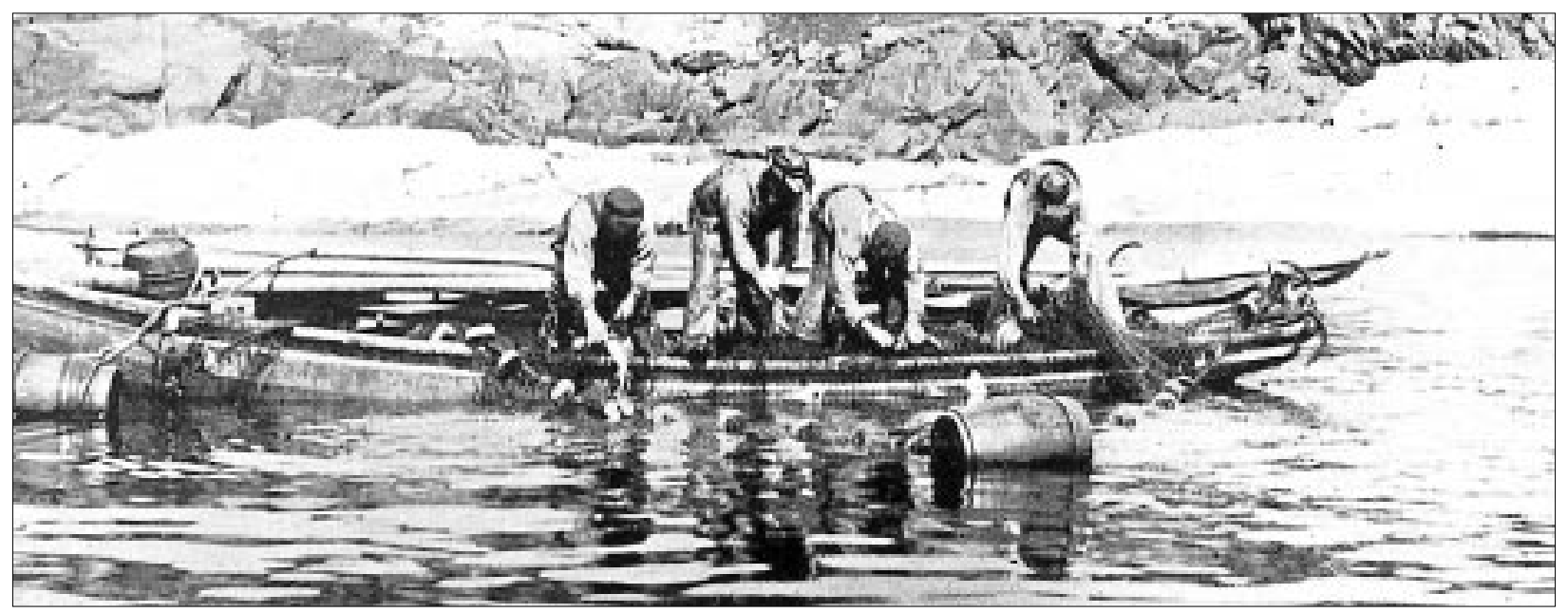

Fig. 11. Hauling a cod-trap at Indian Harbour, Labrador in 1905. (Courtesy of the National Archives of Canada; Neg. No: C46721).

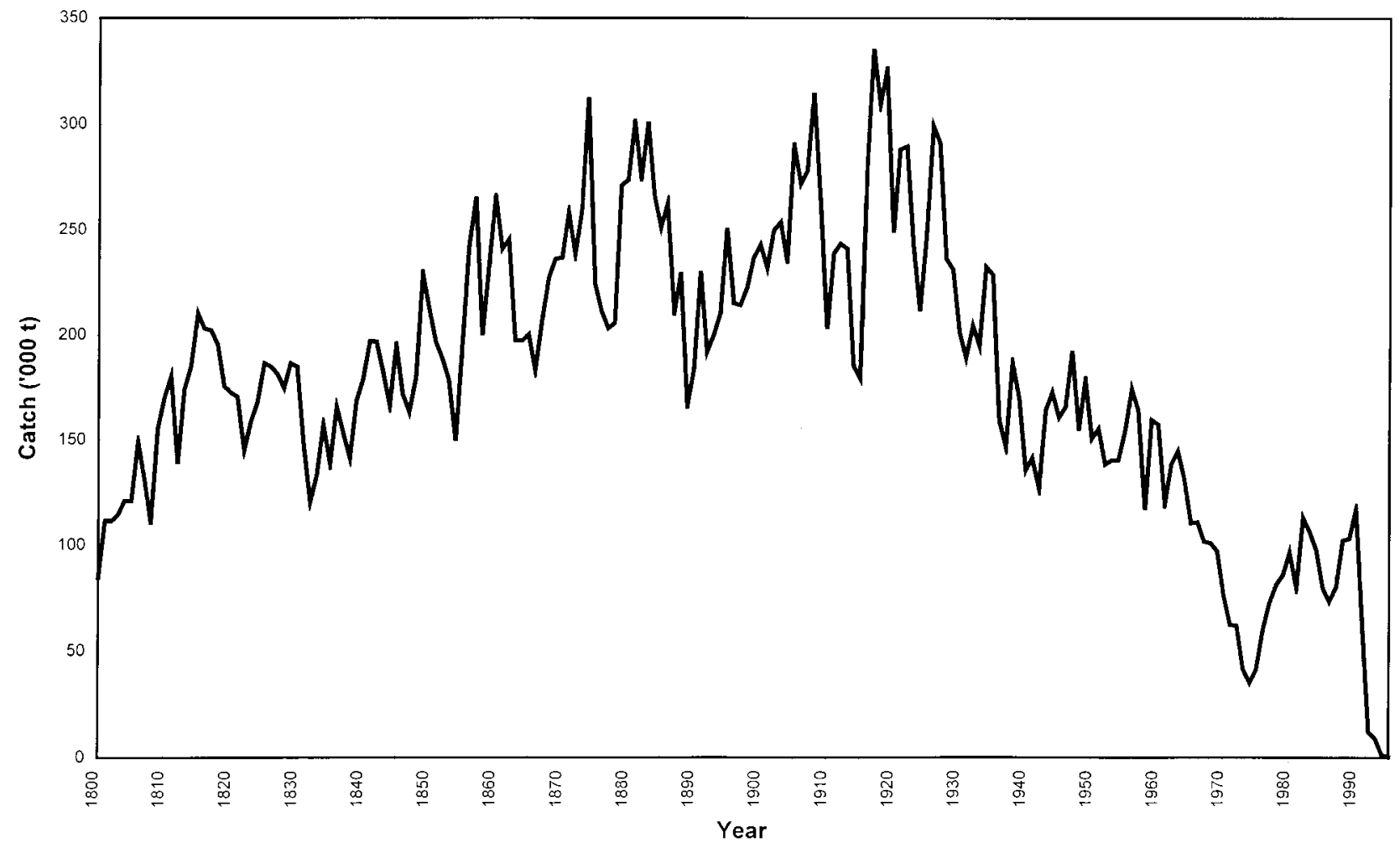

Fig. 12. Inshore catches of northern cod from NAFO Div. 2GH3KL during 1800-1995. 
were destitute, living on government hand-outs of corn meal and molasses, and unable to pay their debts; consequently the merchants were also in dire financial straits. Munn (1938) elaborates:

"For some reasons, never explained, the salt water around our Country became hostile to fish life. The old fishermen still tell us the water was perfectly clear, and you could see objects on the bottom in twenty fathoms of water. The nets moored in the water would become filthy with slime. The codfish could not live in it, and the spawning or reproduction must have been brought to a stand still. The fishermen reported a failure in the catch in all directions, both on the Newfoundland shore and Labrador .... This became acute in 1862, and got worse and worse during the next five years."

The Conception Bay fishing fleet, reduced from 212 sailing vessels in 1833 to 85 by 1861 , produced lower catches: in 1863 some Conception Bay vessel owners began to pursue the winter cod fishery from Rose Blanche, and other merchants began to invest in the newly introduced steamships (Smallwood, 1967).

The seal fishery had been practiced in Newfoundland since the early-1700s (Head, 1976; Ryan, 1994). The planters on the east coast of Newfoundland first began to seek out the seals on the ice fields in 1793. By 1803 about 53000 seals had been reported taken. By 1818 it rose to about 165000 . By 1850-60, Newfoundland annual production of seal skins was about 300000 to 500000 (Ryan, 1994). This increased activity lengthened the season for fishing vessels and added to the increasing prosperity of the Island (Fig. 13).

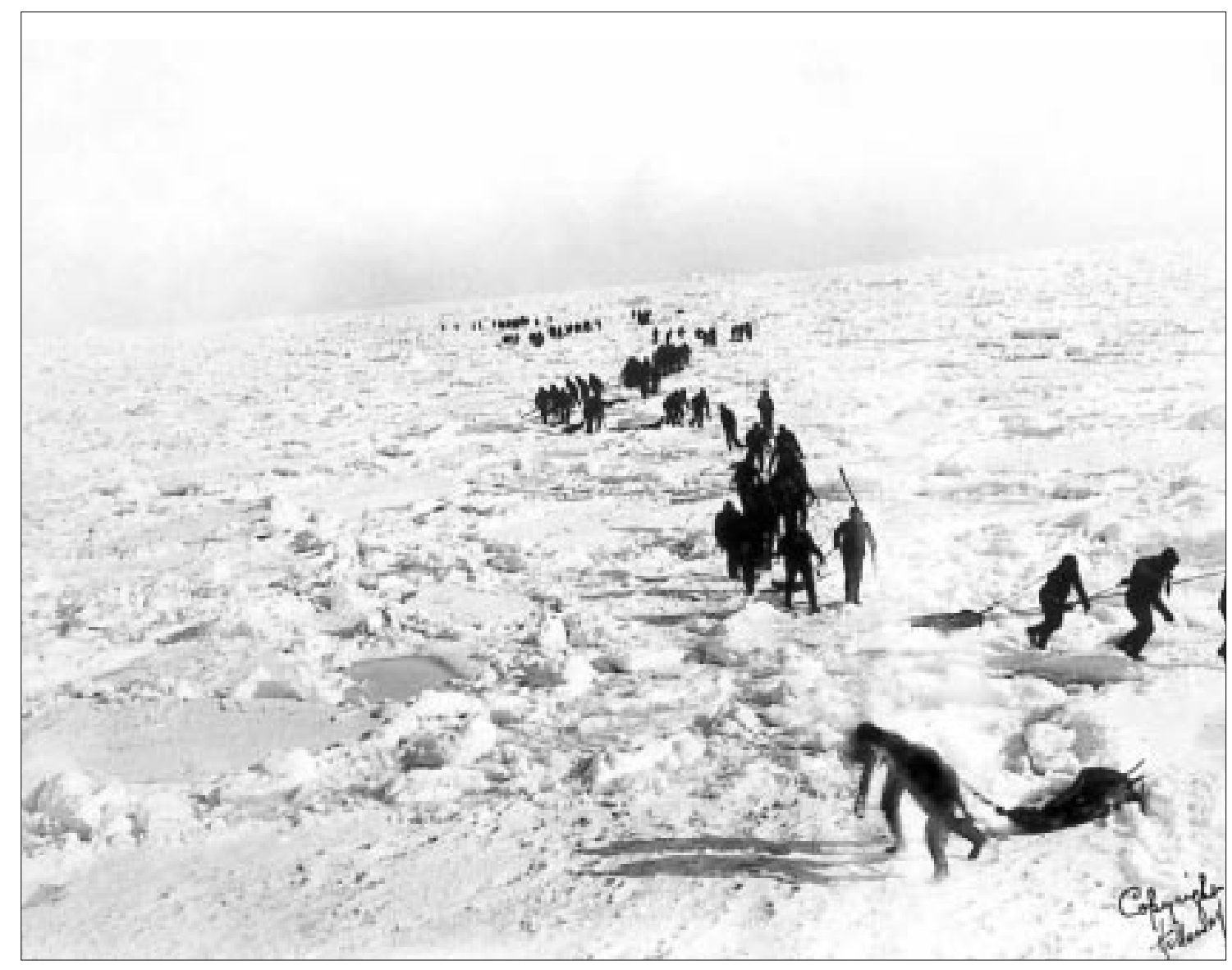

Fig. 13. Sealers hauling seal pelts to sealing vessel. (Courtesy of the Provincial Archives of Newfoundland and Labrador; Neg. No: A8-128). 


\section{Nova Scotia, New Brunswick and Quebec}

After the loss of New England from the British Empire as a result of the American War of Independence (1776-83), Nova Scotia secured the advantage of the British commercial system (Innis, 1940). The fishing industry became the source from which commercial intents emerged. The struggle with the West Indies carried on by New England under the old Empire was continued by Nova Scotia in the new Empire. Nova Scotia opposed the admittance of American fish to the British West Indies and attempted to restrict the New England fishery. The exclusion of the United States from the British West Indies fish market contributed to the expansion of shipbuilding, lumbering and fishing in New Brunswick and Nova Scotia. For example, New Brunswick built 93 square-rigged vessels and 71 sloops and schooners during 1783 to 1793. Similarly, such industries increased the Shelburne population to 12000 and towns such as Canso became strategic fishing ports. In 1789 the total exports of cod from Nova Scotia were estimated at 20000 quintals (4 960 tons) while by 1806 about 100000 quintals (24 800 tons) of cod were exported from Halifax alone.

The commercial interests of Nova Scotia attempted not only to exclude American fishermen from Canadian waters and to exclude American trade with the West Indies, but also to build up the fishery and the trade with Canada (Innis, 1940). The bounty system of granting subsidies was extended and modified in 1810 and 1811. A scarcity of salt in 1814 as a result of war, resulted in a petition to the Nova Scotia House of Assembly which granted a bounty in 1815, which kept the average price of salt stable. Assistance of other types such as bounties were granted to mackerel and other fisheries. The catch of mackerel at Digby increased from 630 barrels (about 125 tons) in 1824, to 600 tons in 1825 and to about 1100 tons in 1826. In Nova Scotia, about 10000 men were employed in the fishery. They caught about 120000 quintals (29 760 tons) of codfish. Yarmouth shipping increased from 26 vessels in 1790, to 41 in 1808 and to 65 in 1828. In 1824 Lunenburg exported 20000 quintals (4 960 tons) annually, one third from the shore fishery. It had more than 100 vessels engaged in the coastal and foreign trade and in the fishery. During 1824 and 1825 an average of 50000 barrels (about 12400 tons) of mackerel were caught around Chedabucto Bay. On the Bay of Fundy, up to 1819, Digby had reported local production of from 60000 to 100000 half-bushel boxes of herring. In 1830 between 100 and 200 Nova Scotian and New Brunswick vessels sailed to Labrador. These vessels represented a total tonnage of some 6000 to 7000 tons and carried about 1200 men (Innis, 1940). By 1841 about 400000 quintals (99 200 tons) of cod were exported from Nova Scotia. In 1851 arrangements were made with New Brunswick for the protection of the fisheries. This involved the use of two vessels for efficient protection of fisheries. In 1852 the Committee of the Nova Scotia Assembly recommended the selection of four fast sailing vessels to seize all foreign fishing vessels within the three-mile limit (Innis, 1940).

In New Brunswick, Shippegan had 60 boats engaged in fishing, Point Miscou had 20, with the largest being at Caraquet with 200 boats. In 1832 this area produced about 24000 quintals (5 950 tons). On the Gaspé Peninsula the Jersey firms extended their fishery. By 1856 fishermen from Bay of Chaleur and Gaspé had extended to Natashkwan, Magpie Bay and Seven Islands in the northern Gulf of St. Lawrence. By 1857, it was estimated that along the coast from Godbout to Blanc Sablon, there were 1225 employed in the fishery and 300 fishing vessels. They caught about 33000 quintals of cod, 2235 barrels of herring, 700 barrels of mackerel, 1200 barrels of salmon and 5730 seals. In 1876, 17 firms engaged in shipping fish from Europe had 30 establishments on the North Shore.

The change in the Quebec Resolutions at the London Conference in December, 1866, gave the federal government control over seacoast and inland fisheries (Innis, 1940). After Confederation of 1867, a federal Act was passed in 1868 incorporating the main features of earlier maritime legislation. Some of them were:

1) Governor may grant licences to fish within three miles of the coast.

2) Officers may board vessels within any harbour of Canada.

3) The officer may bring the vessel into port and search the cargo. If foreign, and found to be fishing without a licence, the vessel stores and cargo shall be forfeited. 
The Canadian Confederation and the Treaty of Washington between Canada and the United States involved not only the opening of the American market. The expansion of the Canadian Steamships to Quebec and Montreal and the completion of the Intercolonial Railway contributed to the development of the fresh fish industry. Lunenburg ships followed American vessels in withdrawing from Labrador; and, in the 1870s they adopted the technique of trawl-line fishing on the Banks. The Nova Scotian fishery reached its peak in the early-1880s as the extension of steamship services brought disaster to the sailing vessels. Nova Scotia profited by the inauguration of a steamship service to the West Indies and Brazil in 1881, the development of the bank fishery, and the payment of bounties which began in 1882 (Innis, 1940).

During the 1880s Nova Scotia had assumed a position in the forefront of the struggle for control over legislation dealing with the fishery (Innis, 1940). The production of dried salted cod in the Atlantic Coast fisheries reached a peak in the 1880 s. Decline set in thereafter as the result of a gradual accumulation of factors, including:

a) the decay of numerous ports with the disappearance of wooden shipping,

b) a weakening of the market in countries dependent on cane-sugar production, with the development of beet sugar,

c) competition from other food products, and

d) the appearance of outlets for fresh fish.

By the close of the century, lobstering (Fig. 14) had begun to rival the traditional cod fishery (Gordon et al., 1956).

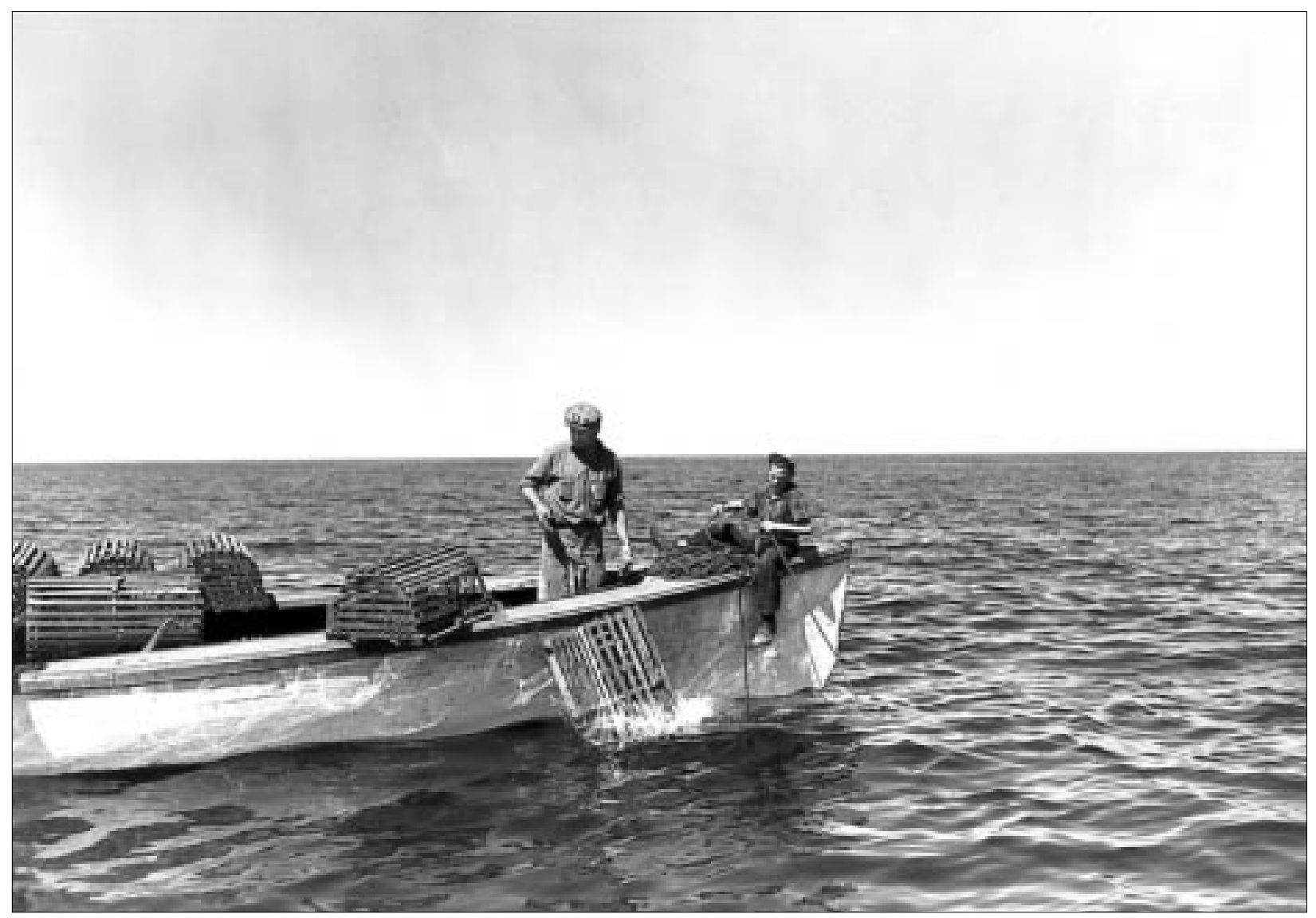

Fig. 14. Lobster fishing off the south coast of Prince Edward Island, September, 1948. (Courtesy of the National Archives of Canada; Neg. No: PA115132). 
The regulation of the fishery increased as a result of increased awareness and the potential strength of the Fisheries Act of 1868. The rules for the Dominion were only a few pages but they were wide-ranging. The Fisheries Branch by the 1870 s already used almost every method of regulation that would appear later. They could control who would fish, how, when, where and for what. The Fisheries Branch already granted licences for both common property and quasi-private fisheries. It already applied what we now call the "user-pay" principle with a landings tax on salmon (Gough, 1991). These Canadian regulations remained very much ad hoc. Most attention went to the river and estuarine fisheries. In 1876, an Order-inCouncil forbade the use of explosives in fishing (Gough, 1991).

\section{United States}

The American Revolution had a tremendous impact on the New England cod fishery. Some of the fishermen left their trade to become seamen in the new navy, some became privateers and many simply ceased fishing on the banks during the years of hostilities (Jensen, 1972). The Treaty of Paris, ratified by Congress in 1783, gave the Americans fishing rights off the Canadian coast, on the Grand Banks and other Banks of Newfoundland and in the Gulf of St. Lawrence. A prohibition against drying of fish on the shores of Newfoundland posed a problem to those American fishermen who made the long, hard journey by sail to the Grand Bank. Since they had to take their boat-load of wet salted cod back to New England to dry, fishing trips could only last a month instead of the usual six months (Jensen, 1972).

During the early-1800s, the fisheries entered a period of expansion and change. There was a slow recovery following the decline caused by the war, but soon American fishermen were exercising their new treaty rights on the rich cod ground in the Gulf of St. Lawrence and off Labrador. Other ships fished the Grand Banks. Coastal towns in New England sent every able bodied man and boy to the cod fishery (Jensen, 1972). Between 1790 and 1810 about 1230 New England fishing vessels sailed each year, half of them to the Grand Banks and the other half to the Bay of Chaleur and Labrador.

During the early 19th Century, New Englanders introduced new fishing methods that added more danger to the fishery. One of these took the fishermen off the vessel and into twelve-foot dories to work their handlines. In this way the fishermen could operate over a wider area than they could when all the men fished from the large vessel.

The dories were nested in two stacks amidships on either side of the main deck of the vessel. Each morning on the fishing banks, before sunup, the small fleet of dories was launched from the mother ship and each afternoon it returned to the mother ship, where the fish were unloaded and the dories hoisted back aboard (Jensen, 1972). In the 1850s some of the vessels began to fish with a "bultow", or line trawl, a longline with several hundred baited hooks attached at intervals. The gear had been developed by the Dutch in 1770, was taken up by the French, who introduced it to the Americans. At first, the bultow was set from the mother ship but soon the dories were put to use to set the gear and haul it back. The bultow was not universally accepted by American fishermen, but those who did use it found it greatly increased their catches. Canadian fishermen objected to the Americans using the new gear in Canadian waters because they were certain the stocks of cod soon would be depleted. However, a move to have the bultow banned came to nothing (Jensen, 1972). In 1879, about 92 million pounds of cod were landed by the salt bankers. In 1880, a record was set that has never been equaled when 294 million pounds of cod were landed.

The first recorded serious attempt to fish at Georges Bank was made in 1821 by three Gloucester vessels. However, the Georges Bank cod and Atlantic halibut fisheries were not established as a permanent industry until about 1835 , and in the following 15 years the catches mainly consisted of halibut (Merriman, 1982). The fisheries expanded offshore as inshore stocks of cod were depleted and the variety of species sought increased (German, 1987).

Atlantic halibut markets expanded in Boston and elsewhere in the 1820s and the demand began to outstrip the inshore supplies. By 1836 a major halibut fishery, by 30 vessels, had developed on Georges 
Bank. Vessels anchored at the Bank and fishermen fished over the rails with handlines. For nearly a decade, halibut were so plentiful on the banks that vessels could catch 15000 pounds in one day (German, 1987). The fishery reached its peak in 1849 with a catch of three million pounds. By 1850 the halibut stocks on Georges Bank had been significantly depleted and the fishery declined rapidly. By 1835 the Gloucester fleet began to renew the cod fishery on Georges Bank. The Georges Bank cod fishery increased in size and importance after frozen herring, imported from Newfoundland in 1854-55, was used as bait. By 1880, 163 vessels participated in this fishery and landed 12000 tons of cod and 500 tons of halibut. The peak of the Georges Bank cod fishery came in the 1880s. After this it declined along with the demand for salt cod. However, it still continued on a small scale so that as late as 1930, 27 vessels continued to fish with handlines for codfish on Georges Bank (German, 1987). Haddock began to be fished by the 1850s as demand for fresh fish increased. By 1880 about 9000 tons of haddock were landed annually, a significant part coming from Georges Bank. By 1890 Georges Bank provided over $30 \%$ of haddock landings and this proportion increased as haddock became more important in the offshore fishery during 1900 to 1920 (German, 1987).

With Boston as the major center of New England's major market for fresh fish in the 1880s, the market fishery grew in response to demand. This demand was being met increasingly from offshore banks. Market fishermen supplied groundfish of the season: cod, haddock, hake, cusk, halibut and pollock (German, 1987).

\section{From Commercialism to Industrialism (1886-1970s)}

\section{Newfoundland}

Towards the end of the 19th Century and the beginning of the 20th Century, important changes began to take place in the Atlantic fisheries, although these changes were slower to take hold in Newfoundland. The gasoline engine came into use in the small-boat inshore fishery in the first decade of the century (Gordon et al., 1956).

The use of draggers or otter-trawlers was introduced in Atlantic coast waters in 1908. The first trawler began commercial operations in Newfoundland in 1935. This technological innovation met powerful opposition from inshore hook and line fishermen who saw it as a threat to their livelihood. The dragger was a highly efficient instrument of production. It was also expensive and outside the financial means of independent fishermen who perceived that it would undermine their sales outlets. As a result, dragging operations were severely restricted for many years. The intent was to retain the largest possible labour force in the fishing industry. It was thought that the introduction of highly efficient fishing units would reduce employment. The ultimate result of the dragger restriction was to retard the growth of productivity and contribute to low individual incomes in the fishery as a result of the large number of people employed.

During the early years of the 20th Century the development of transportation and of refrigerated fish handling facilities, as well as the growth of urban centers in Canada, had begun to create an outlet for fresh and frozen fish products. Establishment of a refrigerated railway freight service for fish products from both coasts to points in Central Canada was supported by a federal government subsidy from 1909 to 1919. Diversion to fresh and frozen products especially affected the output of salted fish. During World War 1, because of the drop in European supplies, there was increased production of salted dried codfish to fill the demand in Europe. After the war the Europeans restored and expanded their production and improved their cure. This resulted in a shrinking of the European market for Newfoundland salt codfish and Newfoundland turned to the West Indies, which before this had been served by Nova Scotian exporters (Gordon et al., 1956). The ensuing struggle beginning in the mid-1920s, resulted in the forcing down of the price of fish throughout the whole Atlantic coast region. Between 1926 and 1939 it fell on the average more than $50 \%$. As a result the income of fishermen in Newfoundland was reduced to an extremely low

level. It had a devastating effect on the island's economy and has been cited as one of the reasons for the collapse of Responsible Government in 1933 (Gordon et al., 1956). 
During the 1920s the fresh (chilled and frozen) fish trade expanded. This was made possible by two innovations both originating in New England:

1. Filleting at source of production.

2. Quick-freezing.

Filleting at source reduced the transportation costs per unit of edible product and enabled utilization of waste material for by-products. It also resulted in a revolution in packaging and handling of fish products, making possible brand differentiation and the creation of other display values.

Quick-freezing permitted greater standardization of quality and added greatly to the carrying properties of perishable foodstuffs through time and space. It made it possible to avoid or at least minimize fluctuations in supply on the one hand and to extend markets geographically on the other (Gordon et al., 1956).

Newfoundland lagged far behind in these developments. It was not until World War II that the demand for fishery products for both food and industrial purposes was vastly strengthened. The salted cod trade of the Atlantic coast was revitalized and in Newfoundland a filleting and freezing industry was established. After World War II marketing of the Newfoundland production of salted codfish was undertaken by the International Emergency Food Council (IEFC). Inspection of the fish to assure quality, size and grade was compulsory and was carried out by the Newfoundland Fisheries Board and by the Newfoundland Associated Fish Exporters Limited (NAFEL). Price levels were fixed for each grade of fish. The realized values were four times that of the depression years of 1930-33. The IEFC was discontinued in 1947 and the dollar shortage removed the financial support that had bolstered the industry in the immediate post war period. This resulted in a great instability in the industry. As a result of Confederation with Canada in 1949, Newfoundland became part of the high-priced dollar area. Its fishing industry demanded higher prices for a low grade product, thus contributing to the decline of the floater fishery for cod on the Labrador coast (Black, 1960).

The adverse marketing conditions in 1950 and the carry-over of salt codfish from the previous year into 1950 as a result of international restrictions on the free flow of salt fish led to a fall in prices for the Labrador grade product. The result was a sharp reduction in the number of floaters operating on the Labrador coast to 29 vessels in 1951, to 25 vessels in 1952 and to 5 vessels in 1954. Black (1960) observed:

"The cumulative effect of unfavorable marketing conditions upon an industry that was submarginal and uneconomic in its operations resulted in the cessation of the floater fishery in 1954, thereby bringing to an end an industry that had been in operation for almost two centuries".

The years during 1948 to 1965 , and especially after 1953, brought great and rapid changes in the fisheries of the Northwest Atlantic and these changes had a significant impact on the fisheries of Newfoundland and Labrador (Templeman, 1966). It was the final period of discovery of great new resources of groundfish such as cod, redfish and American plaice.

During this period, all the great groundfish populations came under intensive exploitation (Fig. 15). There were great increases in the European fleets, the introduction of European pair trawling and longlining to the Newfoundland area, most significantly the great development of factory trawlers and mother ships in which fresh fish could be filletted and processed on the fishing grounds. These new large factory trawlers were stern trawlers which could fish in much rougher water than the conventional side trawler and hence were more efficient at exploiting fish stocks (Templeman, 1966).

The catches of groundfish increased sharply during the 1960s and decreased during the 1970s (Fig. 16). In particular, the catch of northern cod increased dramatically and peaked at 800000 tons in 1968 and thereafter declined precipitously to 216000 tons by 1976. Catches of cod from all areas of the Northwest Atlantic increased markedly during the 1960s and 1970s (Fig. 17) to a peak of about 1.9 million tons, almost four times the long-term average catch that had been sustained during the period 1895 to 1945 . 


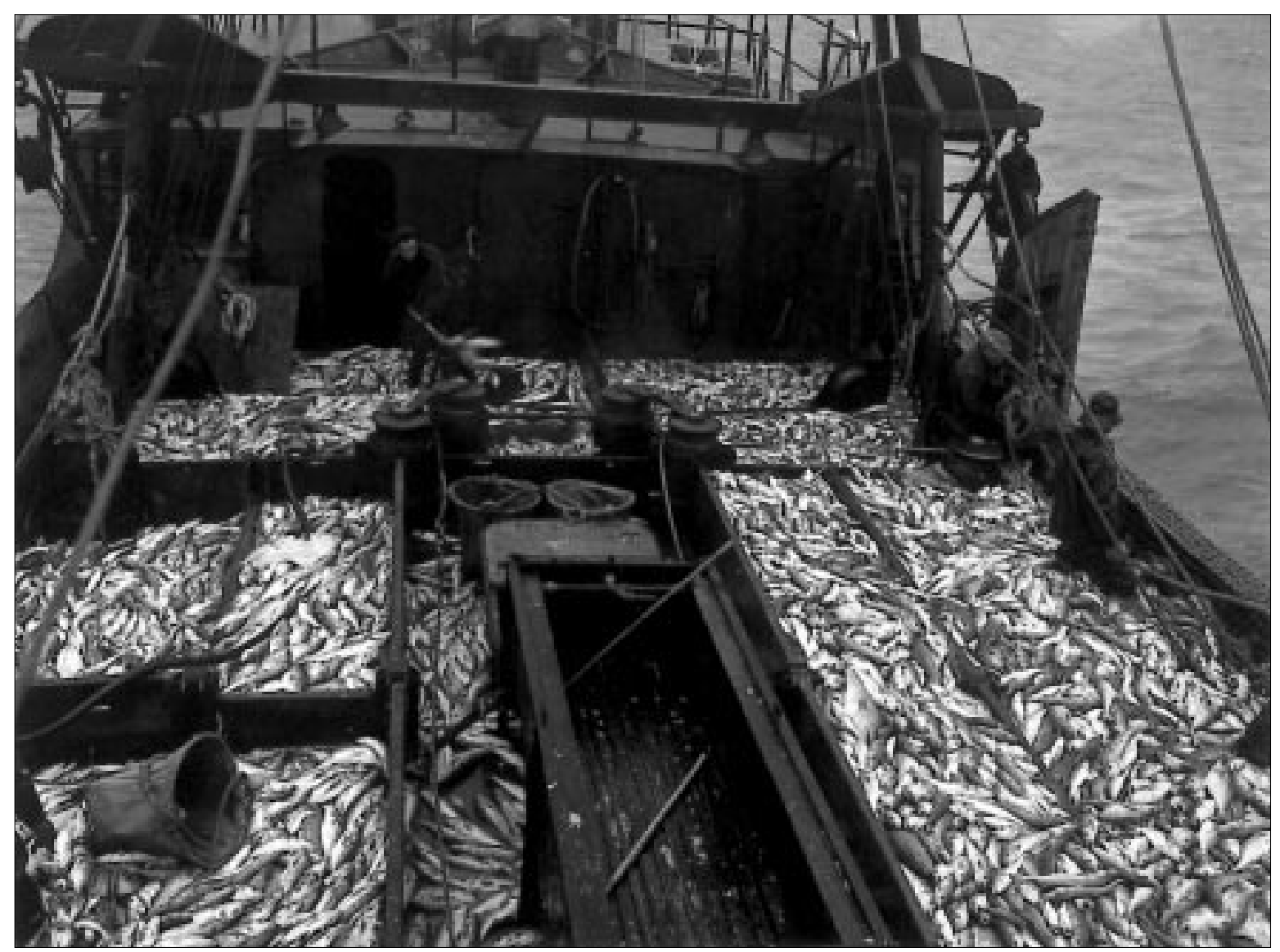

Fig. 15. Trawler with deck load of fish, mainly haddock, from the Grand Bank, 1949. (Courtesy of the National Archives of Canada; Neg. No: PA115449).

Prior to 1950 there were attempts to limit effort and to avoid gear conflicts in the fishery for cod (Lear and Parsons, 1993). These early regulations dealt mainly with mesh sizes in cod nets and cod traps, prohibitions of cod trawls (line trawls) on specific grounds at various times of the year and the designation of cod trap berths by local cod trap committees (Anon., 1943).

When the ICNAF Convention entered into force in 1950, the Commission was given the mandate "to make possible the maintenance of a maximum sustained catch from the (ICNAF) fisheries". This maximum was not defined. The most common interpretation was that the objective was to obtain maximum yield in weight of fish, separately from each stock of fish (Templeman and Gulland, 1965). The early ICNAF regulations dealt exclusively with the regulations of mesh size and construction features of otter trawls (Pinhorn and Halliday, 1990).

As early as 1965 Templeman and Gulland (1965) had stated that further expansion of the fishing effort would produce little or no increase in catch. An increase in mesh size, aimed at protecting small fish would allow only a temporary small increase which would be negated by further expansion of fishing. They advocated that the least difficult method to achieve direct control of the amount of fishing was by means of catch quotas. They suggested that there be separate quotas for each stock of fish and that preferably the quotas should be allocated to each section of the industry. land:

In this regard, there were three meetings of ICNAF that were of particular importance to Newfound- 


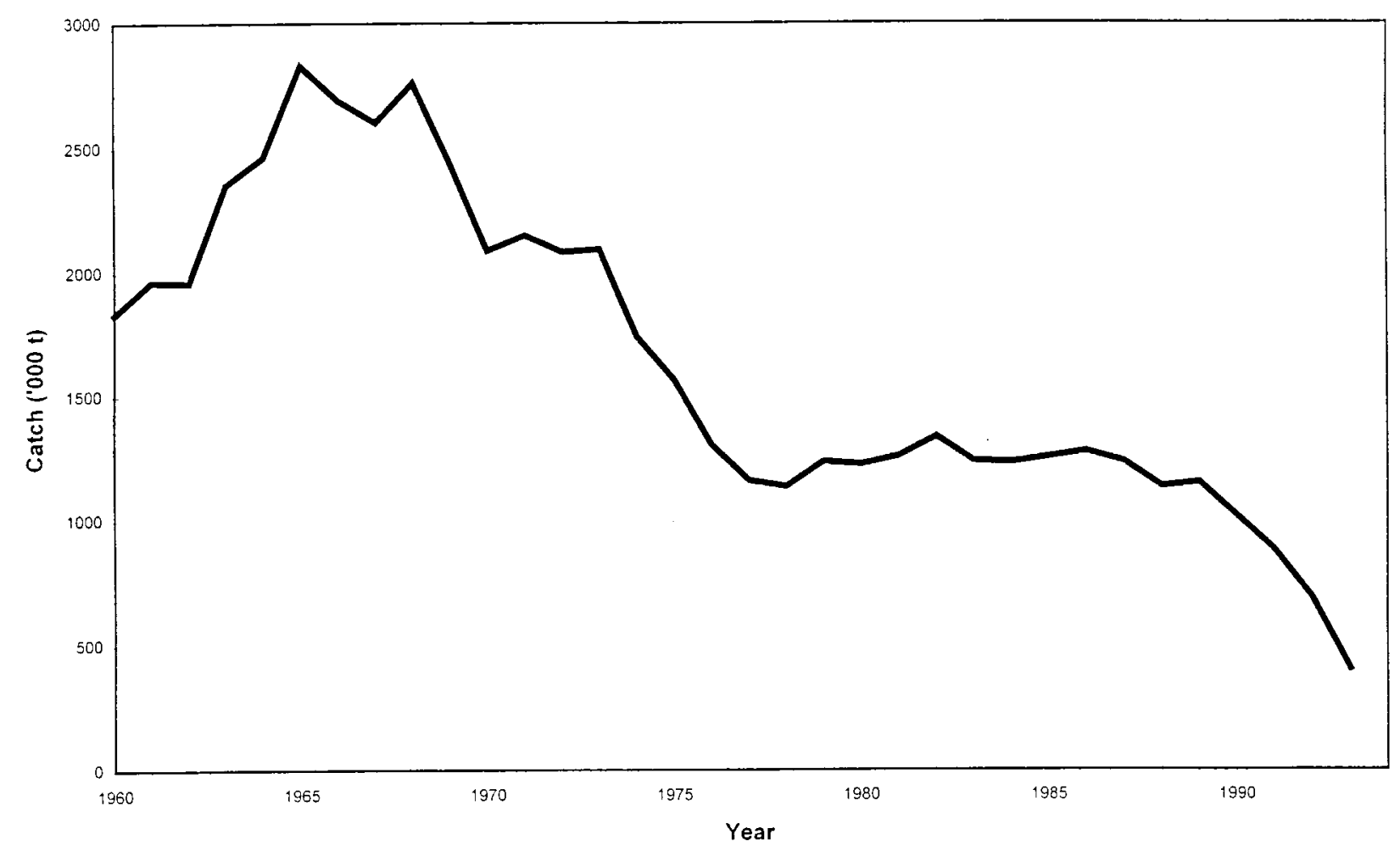

Fig. 16. Nominal catches of groundfish in the Northwest Atlantic, 1960-93.



Fig. 17. Nominal catches of Atlantic cod in the Northwest Atlantic, 1895-1993. 
Annual Meeting - June 1972;

Annual Meeting - June 1973; and,

Special Commission Meeting - January 1974.

At these three meetings, almost all stocks of fish that support directed fisheries in the LabradorNewfoundland area were put under catch quota regulation for the first time. Most quotas established at these meetings were based on the yield-per-recruit curves and set each year as closely as possible to the level necessary to generate maximum yield-per-recruit from the curves. In other words, the catch quotas set for these species should regulate the fishing mortality at the level at which the long-term maximum sustainable yield (MSY) is obtained (Pinhorn, 1976).

For example, for cod in NAFO Div. 2J and 3KL, the TAC set for the Convention Area for 1974 was 656000 tons. The 1975 TAC was reduced to 554000 tons and this was further reduced to 300000 tons for 1976 and even further reduced to 160000 tons and 135000 tons in 1977 and 1978, respectively, as the stock size declined and it was realized that the former TACs had been set too high to allow the stock to recover. ICNAF decided to set TACs at the $\mathrm{F}_{0.1}$ level for 1977 in the context of a Canadian decision to extend fisheries jurisdiction to 200 miles effective January 1977 (May et al., MS 1981). The adoption of the $\mathrm{F}_{0.1}$ strategy appeared to be an attractive economic measure in that theory suggested that only about two-thirds of the fishing effort is required to catch the $\mathrm{F}_{0.1}$ TAC, which in the long-term should produce 85-90\% of the yield-per-recruit at $\mathrm{F}_{\max }$. The $\mathrm{F}_{0.1}$ strategy was considered a conservation measure in that it would provide a buffer against stock assessment error and enforcement deficiencies and would generate a larger spawning biomass to increase the probability of good year-classes occurring (Pinhorn and Halliday, 1990). The more conservative TACs during the mid- and late-1970s appeared to have arrested the stock decline. The biomass of cod age 3 years or older (3+) increased from a low of 450000 tons in 1976 to about 1.2 million tons in 1984 (CAFSAC, MS 1989). This rebuilding was facilitated mainly by the conservative management measures adopted by Canada following extended jurisdiction on January 1, 1977 (Lear and Parsons, 1993).

\section{Canada}

During the period 1869 to 1886 , there was an increase in the groundfish fisheries of Canada, especially of cod. This has been attributed to:

1) The enforcement of the Fisheries Act of 1868,

2) The inauguration of a protection fleet which prevented American vessels from fishing in Canadian territorial waters,

3) Lack of employment in other industries,

4) Payment of bounties to fishermen, and

5) The accessibility of markets in the British and Spanish West Indies and the United States (Grant, 1934).

After 1886 there was a general decline in the groundfish fisheries as a result of:

1) A change in the method of transportation from sailing vessel to steamer,

2) The rise of the sugar-beet industry in Europe which seriously lessened the purchasing power of the West Indies, who traded in cane sugar,

3) The effectiveness of tariffs in restricting markets,

4) Opportunities for employment in other industries,

5) The loss of domestic markets from dried cod as a result of refrigeration and an expansion of the meat-packing industry, and

6) The effectiveness of competition from the salt-cod industries of foreign countries (Grant, 1934). 
The basic structure of the industry remained relatively stable for groundfish, with some changes in the herring fishery, and revolutionary growth in the lobster fishery. The lobster boom built hundreds of canneries, mainly small local operations (Gough, 1991).

The average annual production of dried cod declined steadily from about 791000 quintals (5-year average for 1884-88) to about 486000 quintals (5-year average for 1909-13), to about 298000 quintals (1924-28) (Grant, 1934).

During the early decades of the 20th Century the Canadian Atlantic fishing industry lagged behind in development. There were several causes:

1) Lack of a mass market close at hand,

2) The conservatism of the business community and the scarcity of venture capital, and

3) Political opposition to modernization - draggers were gradually eliminated from the fishing fleets after 1929 (Gordon et al.,1956).

In Nova Scotia some progress was made, mainly in the fresh fish trade. Up to 1930, there was an expansion of sales in central Canada and in the mid-western States of USA. After 1930, growth was more rapid despite adverse tariffs between 1930 and 1936. This development was driven by the trade in chilled fresh fillets of groundfish and live lobster. There was a substantial shift from the cod fishery to fishing for other groundfish species, especially haddock. There was a movement from smaller to larger fishing ports such as Halifax and Lunenburg (Gordon et al., 1956). During World War II, the demand for fishery products for both food and industrial purposes was greatly increased. There was an increase in the salt fish trade. A relaxation of restrictions on the use of draggers initiated a trend toward modernization of the fishing fleets throughout Atlantic Canada. The co-operative movement gained ground among fishermen. A national federation of fish trade associations, the Fisheries Council of Canada was formed in 1945 (Gordon et al., 1956).

In the post war period, there was continued buoyancy in the national economy generally, which sustained a favorable outlook for the demand of fishery products. Progress in the technology of refrigeration, curing, canning and other operations involved in the catching, handling and processing of fish opened up opportunities for new fish products.

\section{United States}

In New England and notably on Georges Bank, the cod, though heavily exploited nevertheless supported the most stable and continuous fisheries (Jensen, 1972). Haddock came to support the major Georges Bank fishery in the 1920s (German, 1987). The haddock fishery was the center of controversy many times for social, political, economic and scientific reasons. Unlike cod, haddock seemed to be more sensitive to fishing.

Between 1930 and 1960, Georges Bank fishermen did not exceed the overall capacity of the stocks to support them. Although effort was directed mainly at a few species, markets allowed others to be substituted if a particular stock declined. An intensive research program on Georges Bank haddock had been initiated by the United States in 1932. In 1949, when ICNAF was established, the foundations were in place for international management of Georges Bank (German, 1987).

Flounder catches grew steadily in the 1930s to meet demand. Up until the late-1950s, fish off the coast of New England were taken mainly by American and Canadian fishermen. In 1961 scouting research vessels from the Soviet Union found fishable herring concentrations on Georges Bank (German, 1987). During the 1960s, expanding distant water factory trawler fleets from Europe began to fish on Georges Bank. They came from more than a dozen countries but primarily Poland, East Germany, Soviet Union, Spain and Romania. By 1965 the Georges Bank trawl landings had increased to 578000 tons from the 
1960 level of 96000 tons. The concentration of a large fleet effort - "pulse fishing" - upon single stocks and areas became the predominant fishing pattern (German, 1987).

The international management measures imposed by ICNAF at the time, such as closed areas and mesh size regulations, were insufficient to control such intense fishing pressure (Fordham, 1996). By the late-1960s, foreign fleets were depleting one fish stock after another: haddock, then whiting, redfish, red hake, mackerel and herring. ICNAF imposed catch quotas in 1973 and stocks began to recover. In 1976, the U.S. Congress passed the Magnuson Fishery Conservation Act. The purpose of the Act (Magnuson Act) was to prevent overfishing, especially by foreign fleets and allow overfished stocks to recover. This Act essentially "Americanized" the fishery off New England and excluded all foreign vessels without special fishing permits from waters within 200 miles of the U.S. coast (Fordham, 1996).

\section{Greenland}

The occurrence of cod at West Greenland was periodical. The two best cod periods were about 1845 to 1856 and the later period, which began about 1920, continuing to the present (Hansen, 1961). The most recent good cod period coincided with a rise in ocean temperatures. The Greenlandic cod population originated from Iceland, and is still closely related to the Icelandic population.

The cod stock decreased suddenly during the earlier period after 1849 and the fishery by English and Danish vessels stopped. From 1850 to 1920 there were only small local stocks in some fjords and occasional appearances during the summer in South Greenland (Hansen and Hermann, 1965).

In 1917 cod appeared in South Greenland (at $62^{\circ} \mathrm{N}$ ), in 1922 off Sukkertoppen (at $66^{\circ} \mathrm{N}$ ) and in 1928 the stock of cod extended its range to Disko Bay at $69^{\circ} \mathrm{N}$. By the 1930 s the cod had extended their range to Upernavik (about $73^{\circ} \mathrm{N}$ ). The general warming of the northern hemisphere around 1920 evidently led to the establishment of a self sustaining and very abundant West Greenland cod stock which, through the 1930 s to the 1960 s, produced good year-classes at relatively short intervals. Since the late-1960s the West Greenland cod stock has produced only few good year-classes and fisheries have dwindled recently to nearly zero catches. At present, cod abundance is at a very low level, with the 1992 catches being the lowest experienced since 1925. The effect of the climate changes in West Greenland on cod stocks appears to be evident but the way those climate changes have affected, and affect, the size of the year-classes is poorly understood (Stein and Llovet, 1996). The catches of cod by the local Greenlanders increased from about 2000 tons during the 1920s to about 20000 tons by 1950 and to 35000 tons by the early-1960s. By the 1950s the total catch of cod at West Greenland was about 250 000-300 000 tons. Catches increased to a peak of 430000 tons during 1967 and declined rapidly to 113000 tons in 1970. Catches further declined to less than 50000 tons during the late-1970s, and then to 7000 tons in 1986. Catches increased in the late 1980s but declined sharply from 109000 tons in 1989, to 20000 tons in 1991 and to 2000 tons in 1993 (Fig. 18).

Catches during the 1960s were taken mainly by Greenland, Denmark, Germany, Portugal, Norway, France, Spain and the United Kingdom. Cod fishing was open for many years except trawling was not allowed inside the three mile boundary. Minimum mesh sizes were set through ICNAF in 1966 and became effective in 1969. The first TAC for cod at West Greenland came into effect in 1974. Since then the West Greenland cod fishery has been regulated by TACs allocated among ICNAF/ NAFO members (Horsted, 1991).

\section{The Present Situation}

Catches of Atlantic cod in the Northwest Atlantic peaked at an all-time high of about 1.9 million tons in 1968 (Fig. 17). During the period from 1895 to 1945, the cod catch fluctuated between about 400000 and 700000 tons but was generally about 500000 tons. During the period from 1895 to 1945 , the overall average cod catch was 513000 tons. It is tempting to speculate that the catches of cod during the 50-year period 1895-1945, represented the sustainable level of harvesting. There is no way to determine if this is so. What can be stated, however, is that they appeared to be sustainable at that level. The question must 


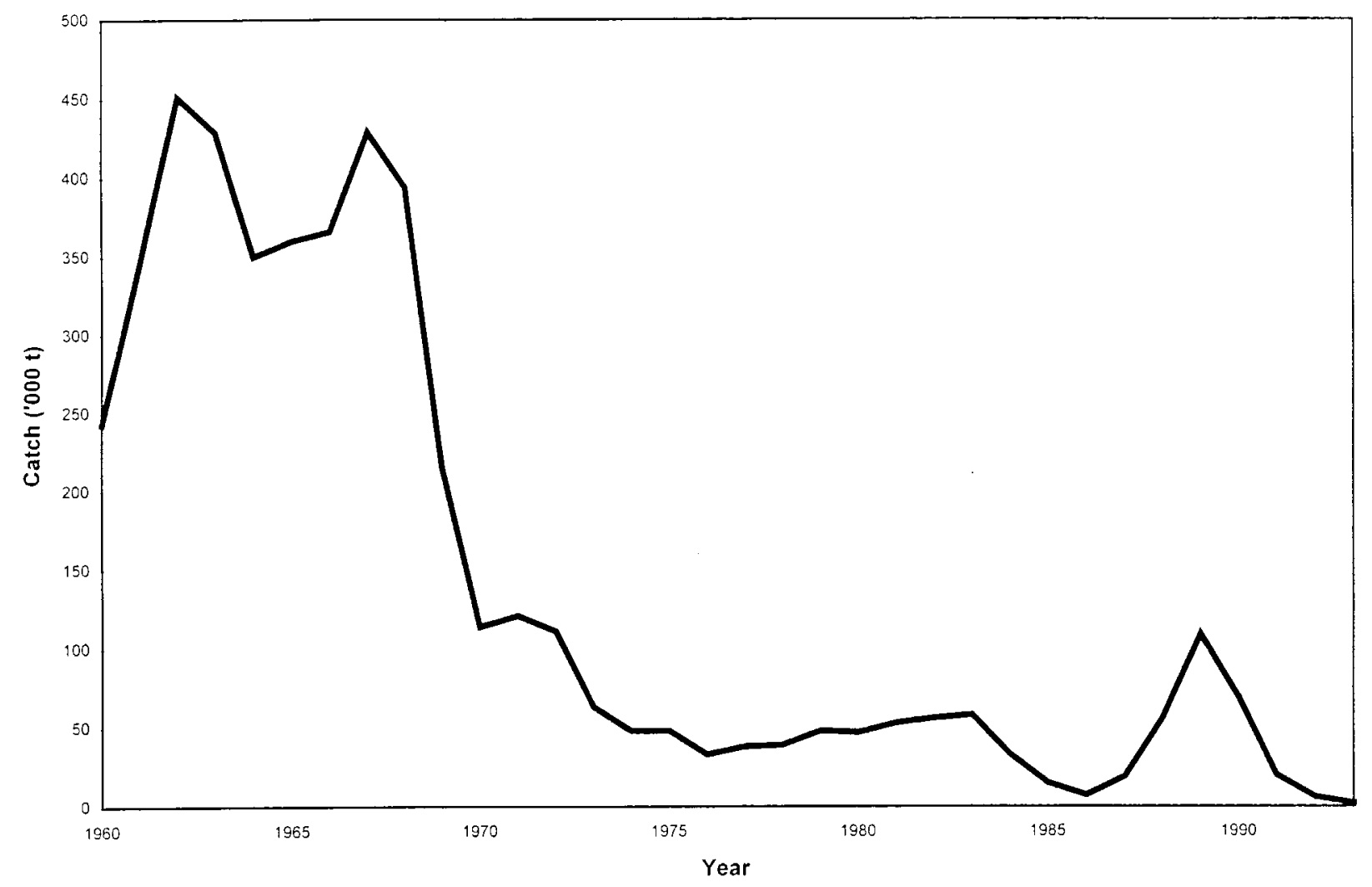

Fig. 18. Nominal catches of Atlantic cod from West Greenland (Subarea 1), 1960-93.

remain unanswered as to whether they may have been sustainable at a higher level of exploitation. Catches after World War II increased sharply and remained remarkably stable for the entire decade of the 1950s at about 900000 tons. During the 1960s the catches rose extremely sharply to peak at about 1.9 million tons in 1968. There followed a precipitous decline to 468000 tons in 1976, followed by a slow recovery to about 700000 tons in the early-1980s. After 1989 catches again fell sharply, precipitating moratoria in 1992 on northern cod and in 1993 on other cod and groundfish stocks in the Canadian zone and the NAFO Regulatory Area to permit stocks to recover. There has been only modest recovery of two of the cod stocks placed under moratoria. Limited fisheries have been permitted on the Div. 4RS and Subdiv. 3Pn stock and the Subdiv. 3Ps stock. There has been no evidence of a significant recovery of the northern cod stock in NAFO Div. 2J and 3KL.

Total groundfish catches in the Northwest Atlantic increased from about 1.8 million tons in 1960 to 2.8 million tons in 1968 and remained above 2.4 million tons until 1970-73, when they were about 2.1 million tons (Fig. 16). Thereafter they decreased sharply to 1.1 million tons in 1978. Catches remained relatively stable around 1.25 million tons during 1979 to 1987 . There was a precipitous drop in catches from 1.0 million tons in 1990 to 120000 tons in 1995.

Catches of haddock fluctuated between about 100000 tons and 200000 tons during the 1950s and the early-1960s and peaked at about 250000 tons in 1965 (Fig. 19). They declined steeply to about 23000 tons in 1974, began a slow recovery where catches reached about 80000 tons in 1980-81, and then declined fairly sharply to about 24000 tons during 1991 to 1992. Biomasses of most haddock stocks have remained low with no signs of good recruitment with the exception of the Div. 4X haddock, whose biomass has started to increase and where the 1993 and 1994 year-classes appear to be strong (FRCC, 1996). Haddock stocks in the Gulf of Maine and on Georges Bank have been showing only small signs of recovery (NOAA, 1995). 


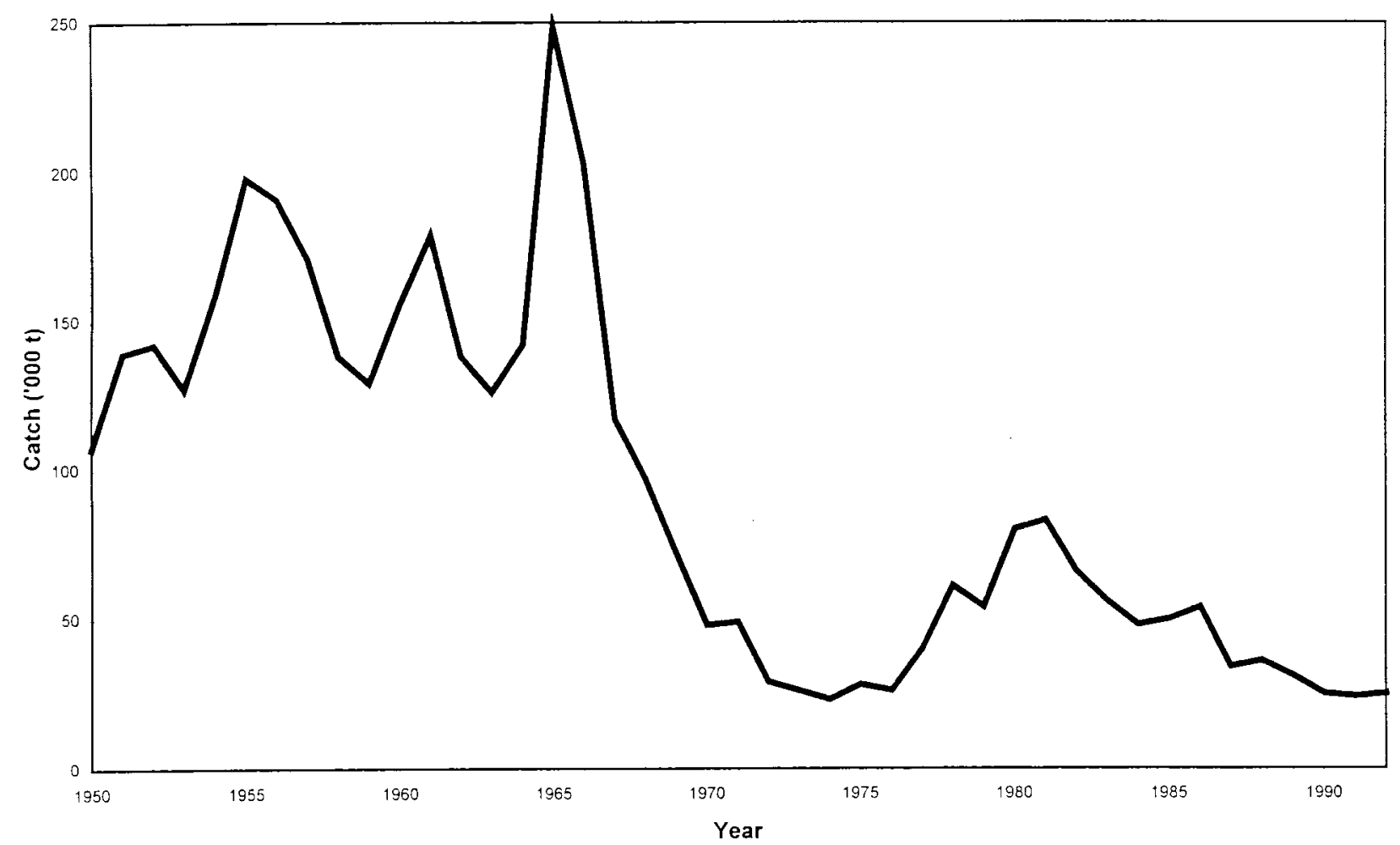

Fig. 19. Nominal catches of haddock in the Northwest Atlantic, 1950-92.

Catches of redfish were about 100000 tons during the early-1950s but increased exponentially to almost 400000 tons in 1959, which is the peak historical catch for the Northwest Atlantic (Fig. 20). During the 1960s catches were generally around 200000 tons and increased to about 300000 tons in the early-1970s and then declined steeply to just above 100000 tons during the early- to mid-1980s. The catch exceeded 200000 tons only in 1987. Since then catches have been in the order of 155000 to 180000 tons. Stocks of redfish on the southern Grand Bank, in the Gulf of St. Lawrence and on the Scotian Shelf appear to be stable with low or moderate fishing mortalities. The biomass of redfish off Labrador and Northern Newfoundland has been low with very poor recruitment (FRCC, 1996). On Georges Bank the stock biomass of redfish has slowly been increasing in the 1990s but remained low relative to the 1960s and 1970s (NOAA, 1995).

Catches of American plaice fluctuated from about 25000 to 40000 tons in the early-1960s, and then increased sharply to about 130000 tons during 1967 and 1968 (Fig. 21). Catches declined and stabilized, with minor fluctuations, at about 90000 tons during 1974 to 1982. After a short decline to about 70000 tons during 1983 and 1984, catches again reached almost 90000 tons during 1985 and 1986, but declined sharply thereafter to about 28000 tons in 1992.

The stock biomass of American plaice on the Grand Bank (Div. 3LNO), the major stock in the Northwest Atlantic, is at a low level with no good year-classes between 1987 and 1993 (NAFO, 1997).

Recently there has been an extensive debate about the possible causes of the collapse of the cod and other groundfish stocks. The reasons for the collapse have been thoroughly studied over the past several years.

Overfishing has been clearly identified as a major factor for the decline of cod and other groundfish stocks, but not the only factor. A more likely explanation is that the combination of high fishing mortality 


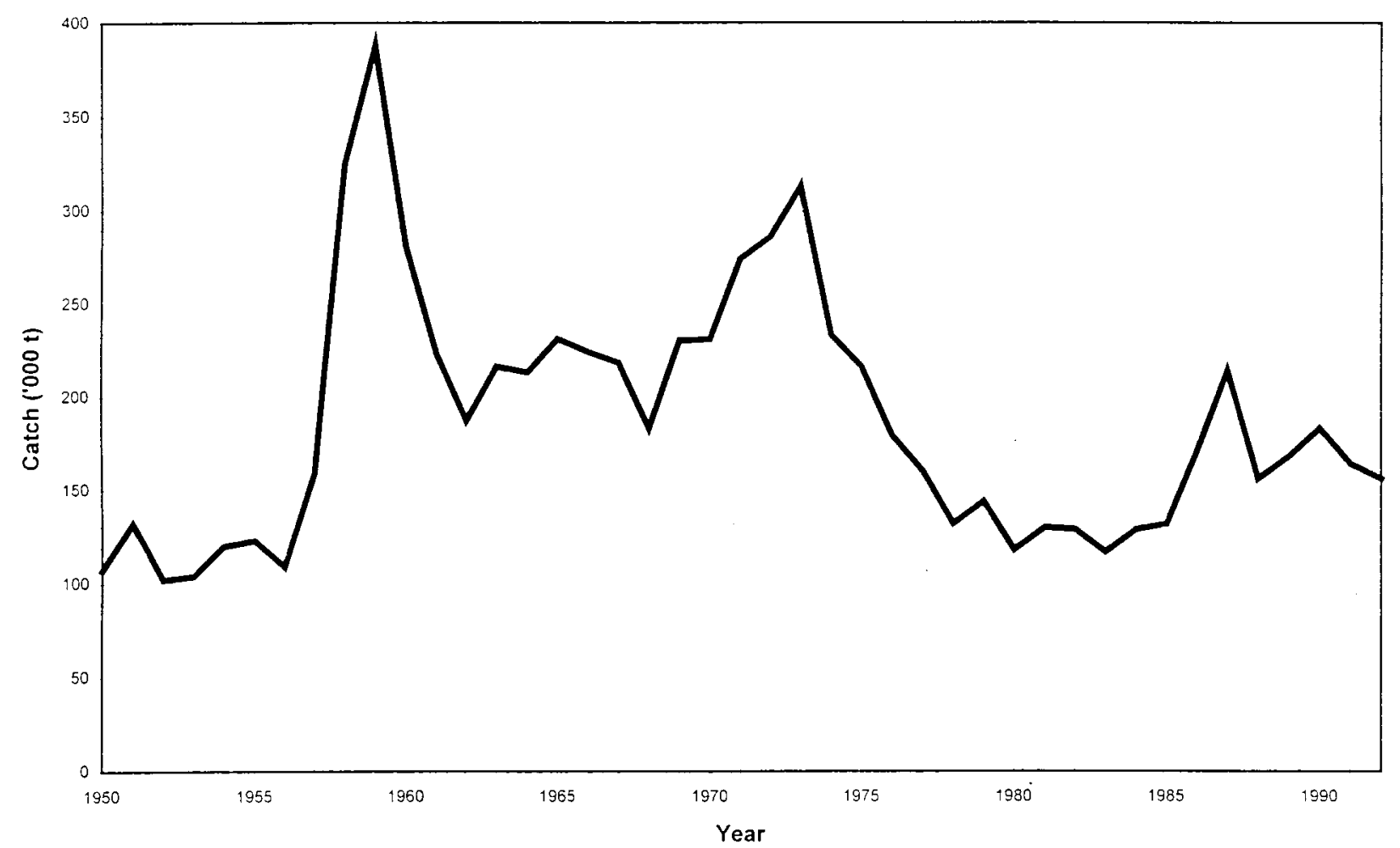

Fig. 20. Nominal catches of redfish in the Northwest Atlantic, 1950-92.

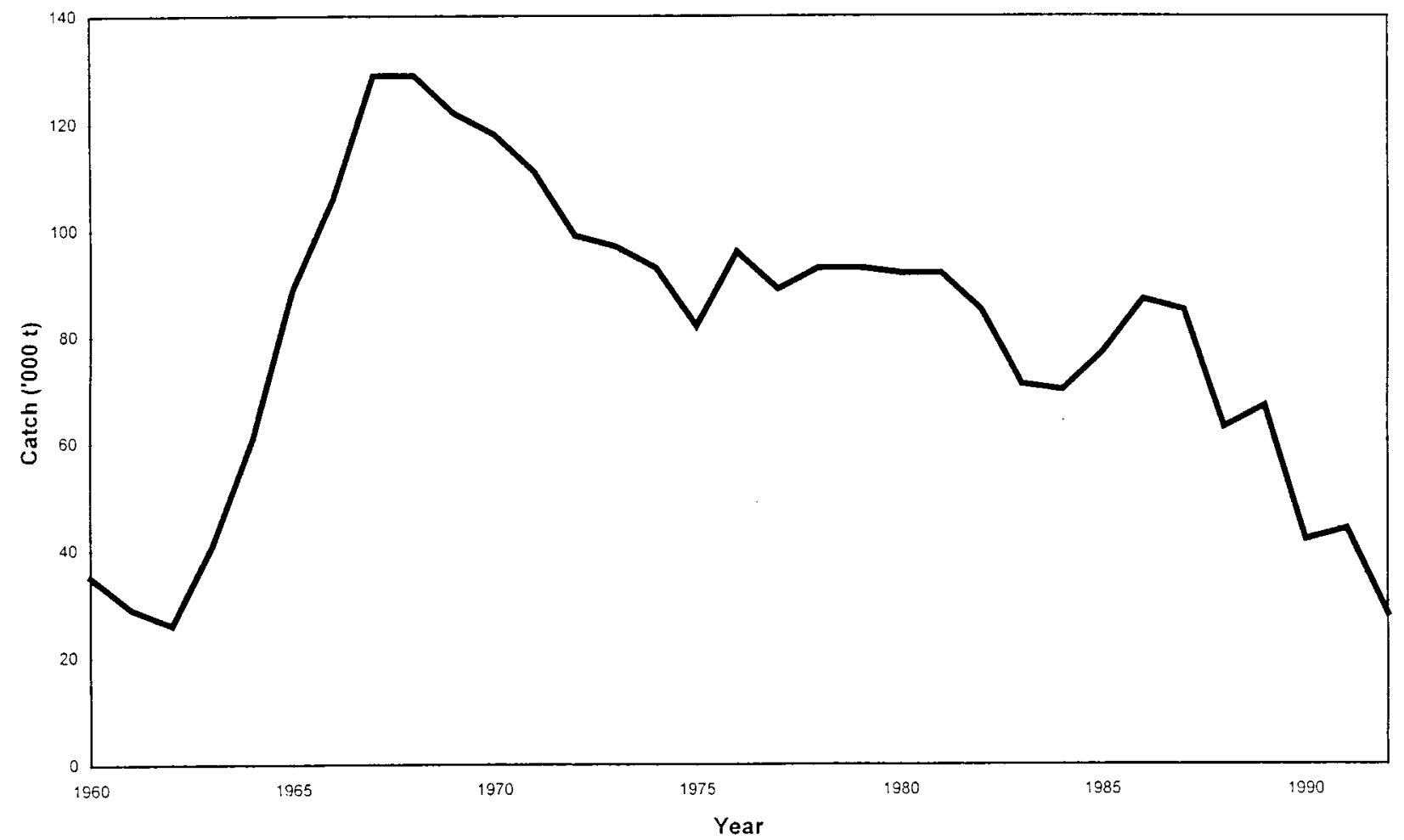

Fig. 21. Nominal catches of American plaice in the Northwest Atlantic, 1960-92. 
and the emergence of harsh environmental conditions contributed to the collapse of some stocks such as northern cod (Parsons and Beckett, 1997).

Two independent reports since the moratorium have commented on the reasons for the decline. The report of the Task Force on Incomes and Adjustment in the Atlantic Fishery (1993) indicated that the following factors had contributed to the collapse:

- Overly high Total Allowable Catch levels, optimistic scientific forecasts, inadequate understanding of stock dynamics, and inaccurate data on commercial fishing activity

- Under-reporting of actual catches which caused harvesting overruns and misleading data for management and scientific assessments

- Destructive fishing practices such as highgrading, discarding and dumping of immature fish or non-target species

- Foreign overfishing of straddling stocks on the Nose and Tail of the Grand Banks

- Failure to control expansion of fishing effort, and failure to minimize the possible adverse impact of fishing gear technologies

- Unforeseen and possible long-term ecological changes which adversely affected the growth, abundance and distribution of various species.

In July 1997, the Fisheries Resource Conservation Council (FRCC) produced a report to the Minister of Fisheries and Oceans entitled "A Groundfish Conservation Framework for Atlantic Canada" (FRCC, 1997). The FRCC, after several years of study, concluded that over-estimation of the biomass; over-estimation of recruitment; failure of the management system to recognize the impact of technological change; excessive harvesting and processing; abusive fishing practices; adverse environmental factors and failure of the political system to make the necessary conservation decisions when the red flag did go up, were the factors that contributed to the collapse of the groundfish stocks. Both reports indicate a combination of factors was responsible. Fishers, processors, scientists, fisheries managers and politicians all made mistakes. Adverse environmental conditions exacerbated the anthropogenic effects. As the FRCC pointed out, "the fishery crisis cannot be related to a single cause or blamed on a single group: it is the failure of our whole fisheries system" (FRCC, 1997).

Overall the prospects for rapid recoveries of groundfish stocks in the Northwest Atlantic do not give grounds for optimism. There are no indications of large year-classes of cod stocks. Under the current stock conditions, there is a need to conserve as much as possible of the spawning biomass. In the interim, the most logical approach is a precautionary one in which we should err, if we err at all, on the side of caution and conservation of fisheries resources. Sustainable fisheries of the future should be based on sound conservation practices and the precautionary approach. These elements are a necessary condition for the rebuilding of the groundfish resources.

If the capture fisheries of the Northwest Atlantic are managed with the first priority on conservation, strict adherence to the precautionary principle, where spawning biomasses are protected and where small fish are not captured or their capture minimized, then the prospects for sustainable capture fisheries are reasonably good given favorable environmental conditions for stock recruitment. If, however, these foregoing principles are not adopted or are severely compromised, then capture fisheries may indeed be a repeat of the past with its legacy of cyclical boom and bust, interspersed with catastrophic stock collapses such as we are now witnessing with northern cod.

\section{Acknowledgements}

I thank Dr. Peter E. Pope, Memorial University of Newfoundland, for reading an earlier draft of the manuscript and providing suggestions and references on the English fishery at Newfoundland during the sixteenth and seventeenth centuries. Christina Matula produced the graphs depicting the catches of various groundfish species. Mr. Francis Kelly, Technographics Division, DFO, Halifax, redrafted the NAFO 
Map to include additional place names. Bridget Mooney and Sylvie Stubbins typed various drafts of the manuscript.

\section{References}

ANON. 1943. Cod fishery regulations. Approved 5th February 1943. Published by authority King's Printer, St. John's, Nfld. 52 p.

ALBION, R. G., W. A. BAKER, and B. W. LABAREE. 1972. New England and the Sea. Wesleyan University Press, Middleton, CT, 299 p.

BABSON, J. J. 1860. History of the town of Gloucester, Cape Ann, including the town of Rockport. Proctor Bros., Gloucester, MA, $610 \mathrm{p}$.

BALCOM, B. A. 1984. The Cod Fishery of Isle Royale, 1713-58. Studies in Archaeology, Architecture and History. Environment Canada, $88 \mathrm{p}$.

BLACK, W. A. 1960. The Labrador floater cod fishery. Ann. Assoc. Am. Geogr., 50(3): 267-295.

CAFSAC. MS 1989. Advice for 1989 on the management of cod in Divisions 2J3KL. CAFSAC Adv. Doc., No. 1.14 p.

DENYS, N. 1968 [1908]. Histoire naturelle des peuples, des animaux, des arbres and plantes de l'amérique septentrionale, et de ses divers climats, Vol. 2 (1672). In: The Description and Natural History of the Coasts of North America (Acadia), Nicholas Denys (ed.). W. F. Ganong. Champlain Society. New York: Greenwood.

FORDHAM, S. V. 1996. New England Groundfish: From Glory to Grief. A Portrait of America's Most Devastated Fishery. Washington: Center for Marine Conservation, $169 \mathrm{p}$.

FORSEY, R., and W. H. LEAR. 1987. Historical catches and catch rates of Atlantic cod at Newfoundland during 1677-1833. Can. Data Rep. Fish. Aquat. Sci., 622: iv + 52 p.

FRCC. 1996. Building the Bridge: 1997 Conservation requirements for Atlantic groundfish. Report to the Minister of Fisheries and Oceans. Fisheries Resource Conservation Council. FRCC.96.R.2, October, 1996. 142 p.+ A82.

1997. A groundfish conservation framework for Atlantic Canada. Fisheries Resource Conservation Council. Ottawa. FRCC. 97. R.3. $50 \mathrm{p}+$ appendices.

GERMAN, A. W. 1987. History of the early fisheries 1720-1930. In: Georges Bank. R. H. Backus and D. W. Bourne (eds.). Mass. Inst. Tech. Press: 409-424.

GORDON, W. L., O. LUSSIER, A. E. GRAUER, A. STEWART, R. GUSHUE, and D. V. LEPAN. 1956. The Commercial Fisheries of Canada. Royal Commission on Canada's Economic Prospects. Prepared by the Department of Fisheries of Canada and the Fisheries Research Board, 193 p.

GOUGH, J. 1991. Fisheries management in Canada 1880-1910. Can. Manuscr. Rep. Fish. Aquat. Sci., 2105: iv + $96 \mathrm{p}$.

GRANT, R. F. 1934. The Canadian Atlantic Fishery. Ryerson Press, Toronto, 147 p.

GRENFELL, W. T. 1909. Labrador: the country and the people. Macmillan, New York, NY, 497 p.

HANSEN, P. M. 1961. Gronlandske Erherv I: Nyttefisk I de gronlandske farvande. Den Kong. Gron. Handel. Kobenhavn. 84 p. [Greenland Occupations I: Commercial fish in Greenland waters. Fish Res. Board Can., Translation Ser. No. 1948.]

HANSEN, P. M., and F. HERMANN. 1965. Effect of long-term temperature trends on occurrence of cod at West Greenland. ICNAF Spec. Publ., 6: 817-819.

HEAD, G. C. 1976. Eighteenth Century Newfoundland: a geographer's perspective. McClelland and Stewart Ltd., $286 \mathrm{p}$.

HORSTED, SV. AA. 1991. Biological advice for and management of some of the major fisheries resources in Greenland waters. NAFO Sci. Coun. Studies, 16: 79-94.

INNIS, H. A. 1940. The cod fisheries: the history of an international economy. Yale University Press, New Haven, CT, $520 \mathrm{p}$.

JENSEN, A. C. 1967. A brief history of the New England offshore fisheries. U. S. Dept. of the Interior, Fish and Wildlife Service, Fishery Leaflet 594, 14 p.

JENSEN, A. C. 1972. The Cod. Thomas Y. Crowell, New York, 182 p.

JUDAH, C. B. 1933. The North American fisheries and British policy to 1713. Illinois Studies in the Social Sciences, Vol. 18, Nos. 3-4, 183 p.

KUNZIG, R. 1995. Twilight of the cod. Discoverer, The World of Science, April 1995. Vol. 16, No. 4: 44-60.

LEAR, W. H., and L. S. PARSONS. 1993. History and management of the fishery for northern cod in NAFO Divisions 2J, 3K and 3L. In: Perspectives on Canadian fisheries management, L. S. Parsons and W. H. Lear (eds). Can. Bull. Fish. Aquat. Sci., 226: 55-89.

LOUNSBURY, R. G. 1969. The British fishery at Newfoundland 1634-1763. Archon Books, 398 p.

MATTHEWS, K. 1988. Lectures on the history of Newfoundland 1500-1830. Breakwater Books, St. John's, Nfld., $191 \mathrm{p}$. 
MAY, A. W., R. G. HALLIDAY, R. WELLS, and E. DUNNE. MS 1981. Management of Canadian cod stocks. NAFO SCR Doc., No. 141. Serial No. N449, 13 p.

MERRIMAN, D. 1982. The History of Georges Bank. In: Georges Bank: Past, Present, and Future of a Marine Environment, G. C. McLeod and J. H. Prescott (eds.). Westview Press. Boulder, Colorado, p. 11-30.

MUNN, W. A. 1938. Harbour Grace history. Chapter Seventeen - The Sixties. The Newfoundland Quarterly, Vol. 37, No. 4: 13-16.

NAFO. 1997. Report of Scientific Council, 4-19 June 1997 Meeting. NAFO Sci. Coun. Rep., 1997, p. 5-171.

NOAA. 1995. Status of the fishery resources off the Northeastern United States for 1994. NOAA Tech. Mem. NMFSNE-108. January 1995, 140 p.

OMMER, R. E. 1991. From outpost to outport: A structural analysis of the Jersey-Gaspé cod fishery. McGill-Queen's University Press, $245 \mathrm{p}$.

PARSONS, L. S., and J. S. BECKETT. 1997. Fisheries management in Canada: the case of Atlantic groundfish. In: Global trends: fisheries management, E. L. Pikitch, D. D. Huppert and M. P. Sissenwine (eds.). American Fisheries Society Symposium 20, Bethesda, MD, p. 73-79.

PINHORN, A. T. (ed.). 1976. Living marine resources of Newfoundland-Labrador: status and potential. Bull. Fish. Res. Board Can., 194: 1-64.

PINHORN, A. T., and R. G. HALLIDAY. 1990. Canadian versus international regulation of Northwest Atlantic fisheries: management practices, fishery yields and resource trends, 1960-1986. N. Am. J. Fish. Manage., 10: $154-174$.

POPE, P. E. 1992. The South Avalon Planters, 1630 to 1700: Residence, Labour, Demand and Exchange in Seventeenth-Century Newfoundland. Ph.D. Thesis, Memorial University of Newfoundland.

1997. The Many Landfalls of John Cabot. University of Toronto Press, Toronto.

PROWSE, D. W. 1895. A history of Newfoundland from the English, Colonial and Foreign Records. Macmillan and Co., London and New York, 742 p.

ROWE, F. W. 1980. A history of Newfoundland and Labrador. McGraw-Hill Ryerson Ltd., 563 p.

RYAN, S. 1986. Fish out of water. The Newfoundland saltfish trade, 1814-1914. Breakwater Books Ltd., 320 p. 1994. The ice hunters: a history of Newfoundland sealing to 1914. Newfoundland History Series: 8 . Breakwater Books, St. John's, Nfld., 525 p.

SMALLWOOD, J. R. (ed.). 1967. Encyclopedia of Newfoundland and Labrador, Vol. 2, Newfoundland Book Publishers Ltd., St. John's, Nfld., 1104 p.

STEIN, M., and J. LLORET. 1996. Stability of water masses - impact on cod recruitment off West Greenland? NAFO Sci. Coun. Studies, 24: 81-86.

TASK FORCE ON INCOMES AND ADJUSTMENT IN THE ATLANTIC FISHERY. 1993. Charting a New Course: Towards the fishery of the future. Fisheries and Oceans, Ottawa, $190 \mathrm{p}$.

TEMPLEMAN, W. 1966. Marine resources of Newfoundland. Bull. Fish. Res. Board Can., 154: 1-170.

TEMPLEMAN, W., and J. A. GULLAND. 1965. Review of possible conservation actions for the ICNAF area. ICNAF Annu. Proc., 15: 47-56.

TURGEON, L. 1987. Le temps des pêches lointaines: permanences et transformations (vers 1500-1850). In: Histoire de pêches maritimes en france, Michel Mollat (ed.). Toulouse: Privat, p. 134-181. 
